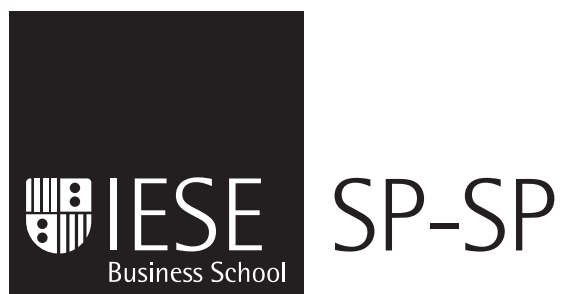

Working Paper

WP no 668

January 2007

University of Navarra

\title{
WHAT DO WE REALLY KNOW ABOUT WHEN TECHNOLOGICAL INNOVATION IMPROVES PERFORMANCE (AND WHEN IT DOES NOT)?
}

\author{
Tunji Adegbesan \\ Joan E. Ricart
}


The Public-Private Center is a Research Center based at IESE Business School. Its mission is to develop research that analyses the relationships between the private and public sectors primarily in the following areas: regulation and competition, innovation, regional economy and industrial politics and health economics.

Research results are disseminated through publications, conferences and colloquia. These activities are aimed to foster cooperation between the private sector and public administrations, as well as the exchange of ideas and initiatives.

The sponsors of the SP-SP Center are the following:

- Accenture

- Ajuntament de Barcelona

- Official Chamber of Commerce, Industry and Navigation of Barcelona

- BBVA

- Diputació de Barcelona

- Garrigues, Abogados y Asesores Tributarios

- Catalan Government (Generalitat de Catalunya)

- Sanofi-Aventis

- Telefonica

- T-Systems

- VidaCaixa

The contents of this publication reflect the conclusions and findings of the individual authors, and not the opinions of the Center's sponsors. 


\title{
WHAT DO WE REALLY KNOW ABOUT WHEN TECHNOLOGICAL INNOVATION IMPROVES PERFORMANCE (AND WHEN IT DOES NOT)?
}

\author{
Tunji Adegbesan* \\ Joan E. Ricart**
}

\begin{abstract}
Most approaches to innovation bear the implicit assumption that increased innovativeness leads to improved organizational performance. Thus more attention has been focused on innovativeness than on innovation performance - on novelty than on value. However recent empirical evidence calls into question the unqualified optimism surrounding innovation, and leads us to ask what we really know about when technological innovation improves performance.

In this paper, we seek to make a contribution by presenting the results of an exhaustive review of the existing knowledge of the outcomes of technological innovation. Our synthesis of the literature allows us to relate, in one parsimonious model, the drivers and moderators of the antecedents, technical outcomes, and performance outcomes of technological innovation and technological change. We also make sense of the proliferation of terms, and consequent terminological ambiguity, which characterize a lot of work on technological innovation. Finally, in the light of the model presented and recent developments in work on firm capabilities, we indicate possible avenues for further development of this critical area of research
\end{abstract}

\footnotetext{
* Ph.D. in Management, IESE

** Professor, General Management, Carl Schroder Chair on Strategic Management, IESE
}

Keywords: Technological innovation, organizational performance, innovation and innovativeness. 


\title{
WHAT DO WE REALLY KNOW ABOUT WHEN TECHNOLOGICAL INNOVATION IMPROVES PERFORMANCE (AND WHEN IT DOES NOT)?
}

\begin{abstract}
"If a man ... make a better mousetrap than his neighbour, though he build his house in the woods, the world will make a beaten path to his door,' claimed Emerson. Yet the inventors of new mousetraps, and other gadgets too, are more likely to be found at the bankruptcy courts than in the millionaires' playgrounds of the Caribbean or the French Riviera" (Grant, 2002: 335).
\end{abstract}

Scholars and managers have spent the last two decades studying the drivers of innovation, and trying to increase firm innovativeness, respectively. These endeavors have been driven by the implicit but generally accepted assumption that increased innovativeness leads to improved organizational performance. Thus more attention has been focused on innovativeness than on innovation performance; on novelty than on value.

However, recent data is beginning to make some observers question the unqualified optimism surrounding innovation. Despite the emphasis on innovation and especially innovativeness, "evidence is growing that innovation processes in many industries are not yielding the benefits they should" (Linder, Jarvenpaa, and Davenport, 2003: 43). Although measures of innovativeness have increased, economic performance has not improved correspondingly (Kandybin and Kihn, 2004; Linder et al., 2003), and surveys repeatedly show that managers are unsatisfied by returns on growth in innovation (Andrew, 2005; Andrew and Sirkin, 2003). Thus "the unspoken truth seems to be that for a very large number of companies, innovation spending continues to rise, but it is generating neither enough profit nor competitive advantage" (Andrew, 2005: 7).

Furthermore, the empirical relationship between innovativeness and firm performance is yet to be demonstrated conclusively. As a whole, studies relating innovativeness to firm performance have provided ambiguous evidence (Li and Atuahene-Gima, 2001), and mixed results are common (Chandler and Hanks, 1994; Haneda and Odagiri, 1998; Leiponen, 2000). A literature review of the area found that two-thirds of the studies showed a positive relationship between innovativeness and performance, but the rest found a negative relationship, or none at all (Capon, Farley, and Hoenig, 1990).

Acknowledgments: We are grateful to Bruno Cassiman and Joaquim Vilà, as well as to Africa Ariño, Johanna Mair, Giovanni Valentini, and participants at the Strategic Management Society meeting in San Juan and the European Academy of Management meeting in St Andrews, for comments on this and earlier versions of the paper. Financial support from the Public-Private Sector Research Centre at the IESE Business School is also gratefully acknowledged.. 
Yet in retrospect these findings are logical, since individual innovations can vary widely in their performance outcomes. An excessive focus on innovativeness masks the innovation-level contingencies that determine the success or failure of individual innovations. Thus an important question arises, which has been insufficiently addressed in the literature: When does innovation improve firm performance, and (perhaps more importantly) when does it not?

To begin to address this question, we need to redirect our attention from the predominant focus on the antecedents of innovation, to the firm-level outcomes of innovation. It is important to characterize what we currently know about the outcomes of innovation in order to delineate the gaps in our knowledge, as well as to identify research programs capable of filling in those gaps.

In this paper, we seek to make a contribution by presenting the results of an exhaustive review of extant knowledge on the outcomes of technological innovation. Our synthesis of the literature allows us to relate, in one parsimonious model, the drivers and moderators of the antecedents, technical outcomes and performance outcomes of technological innovation and technological change (Figure 5). We also make sense of the proliferation of terms, and consequent terminological ambiguity, which characterizes a lot of work on technological innovation.

Our review shows that we know where technological innovation comes from, as well as what makes some firms more innovative than others. Thus there is a very well-developed body of knowledge on the antecedents of technological innovation (Figure 2).

In addition we find that we know a lot about how technological innovation leads to industrylevel technological change. As such, there is also a well-developed body of knowledge on the technical outcomes of technological innovation (Figure 3).

We find that we know quite a bit about how and when industry-level technological change is likely to improve firm performance, and when it is likely to worsen it. Thus there is also a fairly well-developed body of knowledge on the performance outcomes of technological change (Figure 4).

However, we find that we still know very little about when individual innovations will improve economic performance, and when they won't. Thus the clarification of the determinants of the performance outcome of technological innovation represents the next frontier for research on the outcomes of innovation in general, and technological innovation in particular.

By accumulating the aforementioned streams of research (Figures 1-4), we derive the model in Figure 5, which thus summarizes what we currently know about the determinants of the antecedents, technical outcomes, and performance outcomes of technological innovation.

In the next section, we briefly discuss the conceptualization of technological innovation and our organizing framework for the literature review, as well as some descriptive statistics in the review. We then go on to the characterization of the existing knowledge, followed by a discussion of the findings and then the conclusion.

\section{Technological Innovation and Performance Outcomes}

Innovation is the embodiment of new approaches to doing business in products/services and/or their production and delivery systems (Burgelman, Maidique, and Wheelwright, 2001; Grant,

2 - IESE Business School-University of Navarra 
2002). These "new approaches" however, may have different foci. Thus an innovation's novelty may arise from "new approaches" to technology, firm organization, financing, business model etc.; embodied in products or processes (Drucker, 1985; Grant, 2002; Hamel, 2000; Kim and Mauborgne, 1999; Markides, 1997). As Peter Drucker puts it, "innovation goes right through all phases of business. It may be innovation in design, in product, in marketing techniques. It may be innovation in price or in service to the customer. It may be innovation in management organization or in management methods" (Drucker, 1954: 40).

Technological innovation has become more important in recent times, as technical advancement has quickened and grown more pervasive. As a result, firms have increasingly sought to create enhanced value through the embodiment of technical advances or new technologies in products and/or their production and delivery systems. Thus technological innovation is not just the commercialization of new technologies, but innovation, where the focus of novelty is technological. For this reason, it is not confined to "high technology" industries but is, in Drucker's words, "as important to a bank, an insurance company or a retail store, as it is to a manufacturing or engineering business" (ibid). The end product of technological innovation may thus not be a technology itself, but it will embody at least some new technology or technical advance.

Nevertheless, like any other innovation, one of the most important criteria for judging technological innovation has to be its impact on performance. The outcome of technological innovation is critical because an important reason why firms innovate is "to create enhanced value in products and services and to gain sustainable advantage in relation to rivals" (Burgelman and Rosenbloom, 1997: 274). Differences in profitability between competing firms are often a disequilibrium phenomenon resulting from internal or external change (Grant, 2002; Rumelt, 1987), where "internal change is generated by innovation" (Grant, 2002: 231). Hence the characterization of existing knowledge about the determinants of the outcomes of technological innovation is an important task.

\section{One Term, Several Uses}

Unfortunately, this task is complicated somewhat by the fact that scholars investigating the outcomes of "technological innovation" have not used the term in a univocal way. ${ }^{1}$ Three distinct uses emerged from an iterative analysis of the terminology in major English-language journal articles and books on the subject.

Firstly, the term "technological innovation" is sometimes used to refer to an improvement in the performance of a technology (or technologies) along some dimension(s) relevant to the technology in question; even before it is, or can be, embodied in products or processes. This phenomenon is primarily technical, and not necessarily commercial or strategic in nature, as experience shows that many technologies never become commercially viable. Henceforth therefore, we will refer to this phenomenon as a technical advance.

At other times, "technological innovation" is used to refer to the substitution of the core technologies used to develop products that satisfy a particular need, and/or their production and delivery systems. According to Anderson and Tushman, "the core technology of an industry"

\footnotetext{
${ }^{1}$ Table 1 gives an idea of the complexity of analysis required to relate existing studies considering the outcomes of "technological innovation."
} 
often "evolves through long periods of incremental change punctuated by technological discontinuities" (1990: 606). This is an industry-level phenomenon that arises from a complex interaction between technical advancement, innovation, and other social, economic, and political processes. Henceforth therefore, we will refer to this phenomenon as technological change.

\section{Table 1}

Existing Dimensions of Some Concepts in Technological Innovation and Change

\begin{tabular}{|c|c|c|c|}
\hline Concept & Classification & Dimension & Source \\
\hline \multirow[t]{2}{*}{ "Technology" } & Product or process & Technology application & $\begin{array}{l}\text { Wide usage e.g. Butler, } \\
1988\end{array}$ \\
\hline & Sustaining or disruptive & $\begin{array}{l}\text { Impact on established trajectory of } \\
\text { performance improvement } \\
\text { expected by customers }\end{array}$ & $\begin{array}{l}\text { Christensen and Bower, } \\
1996\end{array}$ \\
\hline \multirow[t]{4}{*}{ "Innovation" } & $\begin{array}{l}\text { Incremental, modular, } \\
\text { architectural, or radical }\end{array}$ & $\begin{array}{l}\text { Impact on core design concepts } \\
\text { embedded in components, and } \\
\text { their linkage }\end{array}$ & Henderson and Clark, 1990 \\
\hline & Incremental or radical & $\begin{array}{l}\text { Differential improvement of } \\
\text { innovation over previous state }\end{array}$ & $\begin{array}{l}\text { Wide usage e.g. Abernathy } \\
\text { and Utterback, } 1978 .\end{array}$ \\
\hline & Systemic or autonomous & $\begin{array}{l}\text { Extent to which value is } \\
\text { independent of other innovations }\end{array}$ & Teece, 1987 \\
\hline & $\begin{array}{l}\text { Regular, niche-creating, } \\
\text { architectural or revolutionary }\end{array}$ & $\begin{array}{l}\text { Impact on technological and } \\
\text { market "transilience" }\end{array}$ & Abernathy and Clark, 1985 \\
\hline \multirow[t]{2}{*}{$\begin{array}{l}\text { "Technological } \\
\text { Innovation" }\end{array}$} & Incremental or radical & $\begin{array}{l}\text { Novelty for incumbents, of } \\
\text { technological knowledge-base }\end{array}$ & $\begin{array}{l}\text { Wide usage e.g. Hill and } \\
\text { Rothaermel, } 2003\end{array}$ \\
\hline & Incremental or drastic & $\begin{array}{l}\text { Degree to which previous product } \\
\text { is still a viable substitute }\end{array}$ & Arrow, 1962 \\
\hline \multirow[t]{4}{*}{$\begin{array}{l}\text { "Technological } \\
\text { Change" }\end{array}$} & Incremental or radical & $\begin{array}{l}\text { Degree to which incumbent } \\
\text { technological capabilities made } \\
\text { obsolete }\end{array}$ & $\begin{array}{l}\text { Wide usage e.g. Afuah, } \\
2000\end{array}$ \\
\hline & Incremental or generational & $\begin{array}{l}\text { Degree of improvement within the } \\
\text { same technological paradigm }\end{array}$ & $\begin{array}{l}\text { Lawless and Anderson, } \\
1996\end{array}$ \\
\hline & $\begin{array}{l}\text { Incremental, complementary, } \\
\text { or encompassing }\end{array}$ & $\begin{array}{l}\text { Type of alteration made to "core" } \\
\text { or "complementary" activities }\end{array}$ & $\begin{array}{l}\text { Nagarajan and Mitchell, } \\
1998\end{array}$ \\
\hline & $\begin{array}{l}\text { Competence-enhancing } \\
\text { discontinuity, competence- } \\
\text { destroying discontinuity or } \\
\text { incremental TC }\end{array}$ & $\begin{array}{l}\text { Degree of technical advance; } \\
\text { technological paradigm of the new } \\
\text { technology; and impact on } \\
\text { incumbent capabilities }\end{array}$ & $\begin{array}{l}\text { Tushman and Anderson, } \\
1986\end{array}$ \\
\hline
\end{tabular}

Finally, as mentioned earlier, "technological innovation" may refer to the embodiment of technical advances or new technologies in products/services and/or their production and delivery systems. This usage refers to a firm-level phenomenon with commercial or strategic aims, and is thus perhaps the most conceptually consistent of the three uses of the term. Henceforth therefore, unless used between quotation marks, the term technological innovation (TI) will refer to this phenomenon.

Figure 1 gives a visual summary of the definitional associations between these three uses of the term "technological innovation." 


\section{Figure 1}

Concepts in Technological Innovation and Change

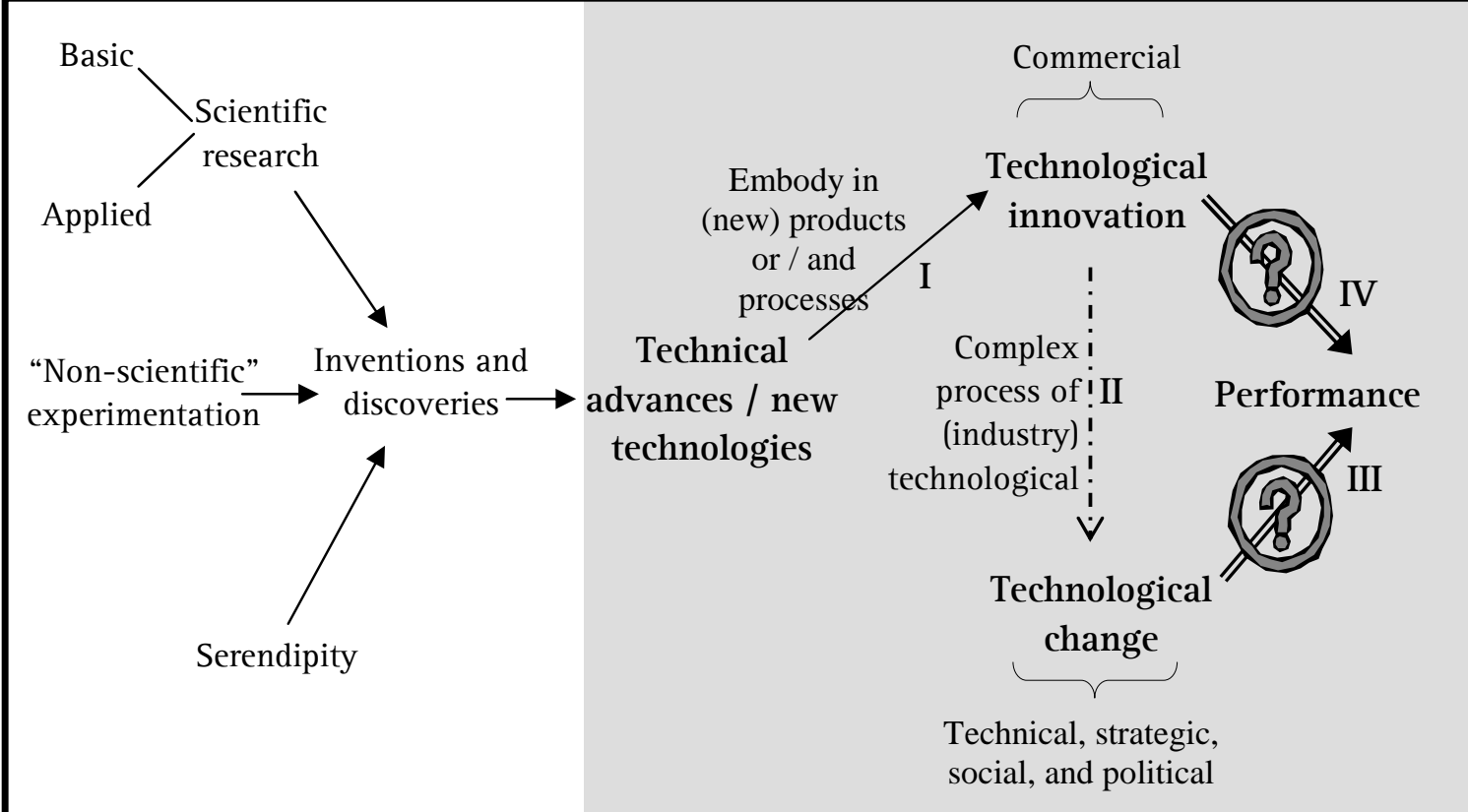

\section{Antecedents and Outcomes of Technological Innovation}

Our distinction between three uses of the term "technological innovation" allows us to show that the various "performance" outcomes in the literature can actually be grouped into two types of outcomes: technical outcomes, and firm performance outcomes properly speaking.

Firstly, one possible outcome of TI is technical in nature. The technology underlying a TI can be so superior to existing alternatives that it triggers a substitution of the core technologies used to satisfy a focal need (Anderson and Tushman, 1990; Cooper and Schendel, 1976; Suarez and Utterback, 1995). This technological change resulting from successful TI is thus a technical outcome.

Secondly however, TI also has direct and indirect firm performance outcomes. On the one hand, the greater or lesser success of TI has a direct effect on firm performance (Banbury and Mitchell, 1995; Christensen, Suarez, and Utterback, 1998; Gatignon, Tushman, Smith, and Anderson, 2002). On the other hand, technological change arising from TI has important effects on firm fortunes (Christensen and Bower, 1996; Henderson, 1993; Henderson and Clark, 1990; Tripsas, 1997), which we can thus consider an indirect performance outcome of TI.

In conjunction with the antecedents of innovation, we use these two types of outcomes to organize the studies in this review, arriving at the four groups of studies outlined in the next section. 


\section{Literature on the Outcomes of Technological Innovation}

The literature on innovation is massive. It remains vast even when narrowed to that portion focusing on the outcomes of technological innovation. This literature shows a remarkable breadth in terms of methodology, empirical settings, theoretical foundations, the variables measured, and the dimensions of technological innovation considered. Thus the choice of a template for organizing this subset of the literature cutting across the categorizations was challenging.

Our review of empirical and theoretical literature on the outcomes of technological innovation used three main sources: articles published in major English-language organizations- and economics-oriented North American and European journals; scholarly volumes edited by the most influential authors in the field of technological innovation and change; and the seminal books or manuscripts which have most influenced thinking on the outcomes of technological innovation. Some descriptive statistics of the sources reviewed are shown in Table 2.

As it was impossible to cover all relevant studies in one review article, we selected studies based on the rigor of their empirical and/or theoretical development; their importance in starting off important lines of thought or investigation; and the degree to which they were cited by others (Brown and Eisenhardt, 1995). We allowed the network of studies to grow forward and backward in time with no constraints (ibid.), and thus arrived at the present review encompassing 31 journals, 16 edited scholarly volumes, and over 30 books; with the temporal boundaries being 1934 to the present.

We used the emergent distinction between three uses of the term "technological innovation" to organize the literature into four groups, roughly corresponding to the numbered arrows in Figure 1. Thus we divided the voluminous literature into studies of: innovation antecedents (arrow I); technical outcomes (arrow II); performance outcomes of technological change (arrow III); and performance outcomes of technological innovation (arrow IV).

Although other classifications of the innovation literature have been used in the past, our focus on firm-level outcomes invariably cut across or over-extended otherwise useful categorizations. For example, one common distinction is that between literature on innovation development and literature on innovation adoption (Rogers, 2003). However, performance outcomes are most pertinent to a subset of the adoption literature which looks at the effects of innovation adoption. Some of the other subsets of this literature stream come with the implicit assumption that successful innovation adoption will improve firm performance. 


\section{Table 2}

Some Descriptive Statistics of the Literature Review

\begin{tabular}{|c|c|c|}
\hline Source & Summary Statistic & Value \\
\hline \multirow[t]{3}{*}{ Journals } & $\begin{array}{l}\text { Number of journals } \\
\text { covered by review }\end{array}$ & 31 \\
\hline & $\begin{array}{l}\text { Maximum number of } \\
\text { articles from one journal }\end{array}$ & 47 (Strategic Management Journal) \\
\hline & $\begin{array}{l}\text { Journals with eight or more } \\
\text { articles (in order of number } \\
\text { of articles) }\end{array}$ & $\begin{array}{l}\text { Strategic Management Journal, American } \\
\text { Economic Review, Management Science, } \\
\text { Journal of Product Innovation Management, } \\
\text { Rand Journal of Economics, Economics of } \\
\text { Innovation and New Technology, MIT Sloan } \\
\text { Management Review, Research Policy, } \\
\text { Academy of Management Journal, } \\
\text { Administrative Science Quarterly, Academy } \\
\text { of Management Review, Harvard Business } \\
\text { Review, and Organization Science }\end{array}$ \\
\hline \multirow[t]{4}{*}{ Books } & $\begin{array}{l}\text { Number of edited scholarly } \\
\text { books }\end{array}$ & 16 \\
\hline & $\begin{array}{l}\text { Temporal boundaries of } \\
\text { edited books }\end{array}$ & $1962-2005$ \\
\hline & $\begin{array}{l}\text { Number of other major and } \\
\text { seminal books }\end{array}$ & 32 \\
\hline & $\begin{array}{l}\text { Temporal boundaries of } \\
\text { major and seminal books }\end{array}$ & $1934-2003$ \\
\hline \multirow[t]{7}{*}{ All publications } & Earliest publication & 1934 \\
\hline & Most recent publication & 2006 \\
\hline & \multirow{5}{*}{$\begin{array}{l}\text { Time distribution of } \\
\text { publications }\end{array}$} & 2005-1999: $25 \%$ \\
\hline & & 1998-1995: 20\% \\
\hline & & 1994-1987: $30 \%$ \\
\hline & & 1986-1979: $15 \%$ \\
\hline & & 1978-1934: $10 \%$ \\
\hline
\end{tabular}

Another common distinction going back at least as far as Schumpeter (1942) is that between invention and innovation, where the latter is seen as the commercialization of the former. Although the literature on invention commercialization is pertinent to our focus on outcomes, it usually overlooks the possibility of non-technology firms incorporating technical advances in their products/services (an issue covered in some of the adoption literature). In addition, the 
inventions in question are often considered inherently valuable, while for our purposes the performance effect is indeterminate ex ante.

Our organizing scheme is thus theoretically motivated, based on our interest in outcomes. The advantage of such a theoretically inspired organizing framework is that it allows indiscriminate attention to be paid to studies examining common issues from diverse perspectives. One disadvantage, however, is the corresponding difficulty in synthesizing findings across different theoretical backgrounds. Nevertheless this difficulty is not insurmountable, but is unavoidable, given this paper's underlying concern with a specific theoretical issue: the determinants of the performance outcome of technological innovation.

In the rest of the paper we review the existing knowledge of the determinants of the outcomes of TI. In doing so, we characterize and present the major findings of the literature on innovation antecedents (i.e. innovation itself as an outcome); technical outcomes; and performance outcomes of technological change and technological innovation.

While studies of innovation antecedents have sought the determinants of the amount of innovation observed and why some innovators are more innovative than others, studies of technical outcomes have investigated the dynamics of technological change arising from TI. Studies of the performance outcomes of technological change have focused on the determinants of the effect of technological change on incumbents and new entrants, in addition to the impact of differential firm strategies for reacting to technological change. Finally, the relatively fewer studies of the performance outcomes of TI, have sought to highlight the determinants of the direct impact of TI on firm performance.

As we will soon see, this last field of study is the least developed of the four, providing, at best, tenuous support for the "pervasive positive bias" (McGrath, Ming-Hone, Venkataraman, and MacMillan, 1996: 392) with respect to the performance impact of TI.

\section{Antecedents of Technological Innovation: Drivers of Innovation and Innovativeness}

Studies of innovation antecedents form the largest subset of work with implications for the outcomes of TI. These studies have focused on the determinants of the amount of innovation observed and on why some innovators are more innovative than others. Thus this field can be

further split into two streams: studies of the drivers of innovation and studies of the drivers of innovativeness respectively.

The first (and older) of the two streams grew out of economists' concern with social welfare. At least since Schumpeter (1934) identified innovation as the motor of economic development, economists interested in the socially optimal level and diffusion of innovation, have closely examined the drivers of the amount of innovation observed. Early work looked at the impact of market power and concentration on innovation, but later work has considered a variety of variables as affecting underlying opportunity and appropriability conditions, and hence the amount of innovation observed. Most of the empirical work in this stream utilizes econometric methodology, and has an implicit assumption that innovation is inherently valuable.

The second stream of work on the drivers of innovativeness is more recent, and grew out of a conviction in both managerial and academic circles that innovation was the key to firm success. Thus it has focused on explaining differing levels of innovativeness across firms in

8 - IESE Business School-University of Navarra 
similar situations. One branch of this stream has sought to explain differential levels of innovativeness in terms of differing firm capabilities in incorporating external knowledge. A second branch has focused on organizational variables such as creativity and the management of the innovation process. The studies in both branches encompass a wide variety of methodological approaches, reflecting the theoretical eclecticism typical of the field of strategic management from which many of them are drawn.

Figure 2 summarizes the major drivers of innovation and innovativeness from both streams, while selected studies are summarized in Table 3.

\section{Figure 2}

Antecedents of Technological Innovation

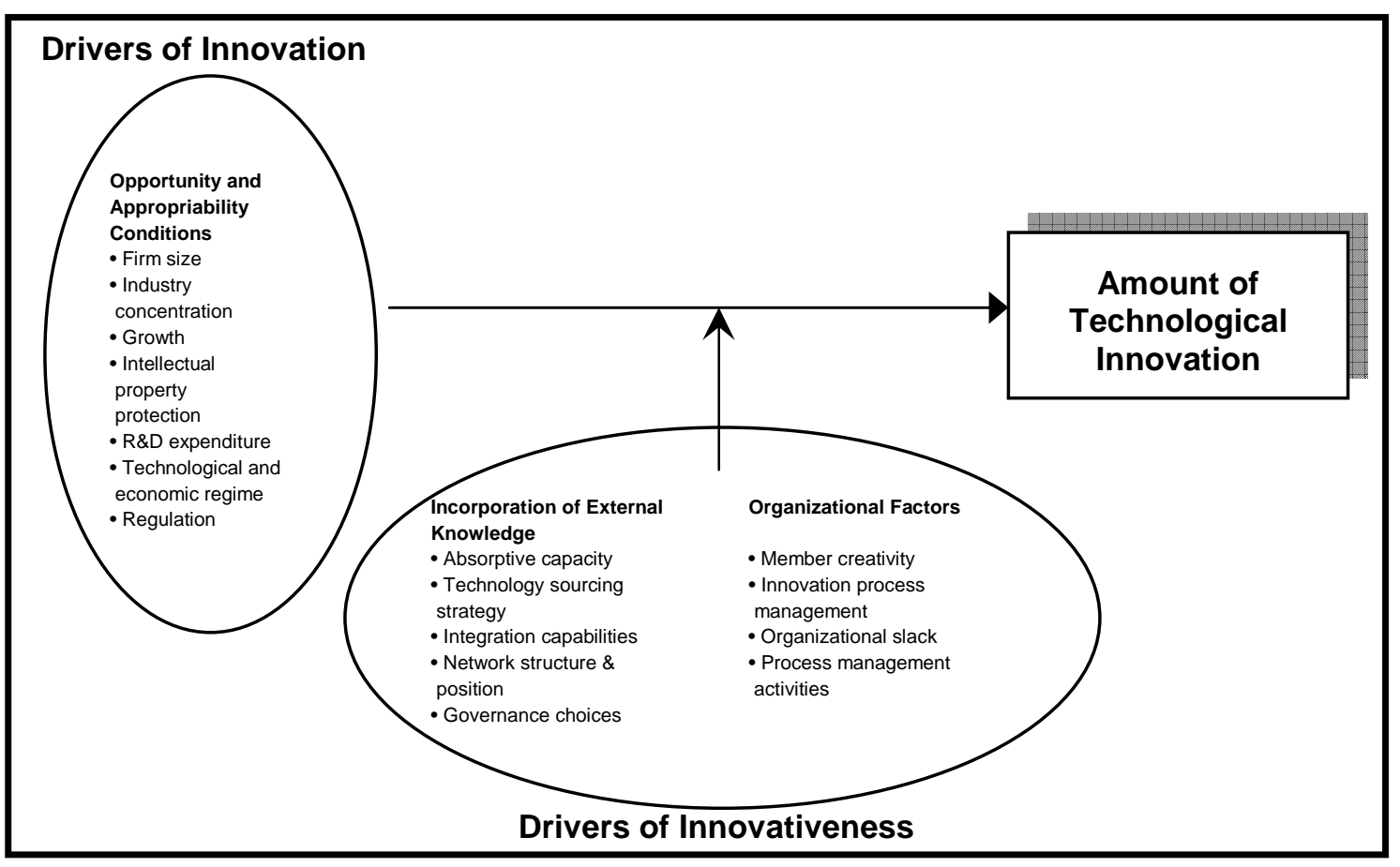

\section{Drivers of Innovation}

"One of the largest bodies of literature in the field of industrial organization is devoted to the interpretation and testing of several hypotheses advanced by Joseph Schumpeter (1942)" (Levin, Cohen, and Mowery, 1985: 20) concerning the determinants of innovative output. According to Schumpeter (1942), large established firms possessing some degree of monopoly power were likely to be the driving force behind technical progress. He suggested that their superior access to capital and skilled labor, in combination with their ability to effectively appropriate innovation, gave them considerable advantages over small firms and new entrants (Henderson, 1993). Additionally, he emphasized that concentration reduced market uncertainty and provided the cash flow required to engage in costly and risky REtD on an efficient scale (Levin et al., 1985). 
In contrast to Schumpeter, other authors argued theoretically that insulation from competitive pressures breeds bureaucratic inertia and discourages innovation (Levin et al., 1985). A seminal article by Arrow (1962) suggested that firms in competitive markets have significantly greater incentives to invest in innovation than do firms in markets characterized by a significant degree of monopoly power. This result, however, was contested by Gilbert and Newberry (1982) who suggested that Arrow's results held only if entry was blockaded. In line with Schumpeter's arguments, they showed that if there was free entry to the industry, incumbent firms with monopoly power would rationally pre-empt potential entrant investment in innovation in order to continue to profit from the extension of existing market power to a new generation of technology (Henderson, 1993).

A subsequent theoretical debate over the issue (Gilbert and Newbery, 1982, 1984a, b; Reinganum, 1983, 1984; Salant, 1984) led to the consensus that whether incumbent monopolists or entrants have greater incentives to invest in innovation is a function of the degree to which innovation destroys existing market power, and of the uncertainty surrounding the innovative process (Henderson, 1993; Lerner, 1997). If the older technology remains viable and the new technology's introduction is not contingent on any single firm's investment, then incumbents have a greater incentive to invest in innovation. On the other hand if the new technology renders the old one obsolete, and its introduction is a function of investments made by each firm, then incumbents with market power will have less incentive to invest in innovation than new entrants (ibid.).

On the empirical front, 40 years of research uncovered no systematic relationship between market power and innovative activity (Cohen and Levin, 1989). Many studies, however, found an "inverted-U" relationship, whereby innovative effort or innovative output first increased with concentration, and then decreased (Levin et al., 1985). Levin, Cohen, and Mowery argued that the ambiguous results were due to the fact that concentration did not have a direct effect on innovation (Levin et al., 1985). They cited studies (Scherer, 1967; Scott, 1984) in which the explanatory power of concentration diminished considerably on controlling for more fundamental technological and institutional conditions, and then went on to replicate the same effect in their paper (ibid).

The emphasis on the importance of underlying technological and institutional conditions was also supported by Winter (1984), who suggested that small- and large-firm innovation responded to distinct technological and economic regimes. He hypothesized that the ability of a firm to innovate was influenced by what he and Richard Nelson $(1974 ; 1982)$ called the underlying "technological regime." Suggesting two types of technological regimes, he posited that "an entrepreneurial regime is one that is favorable to innovative entry and unfavorable to innovative activity by established firms; a routinized regime is one in which the conditions are the other way around" (Winter, 1984: 297). 


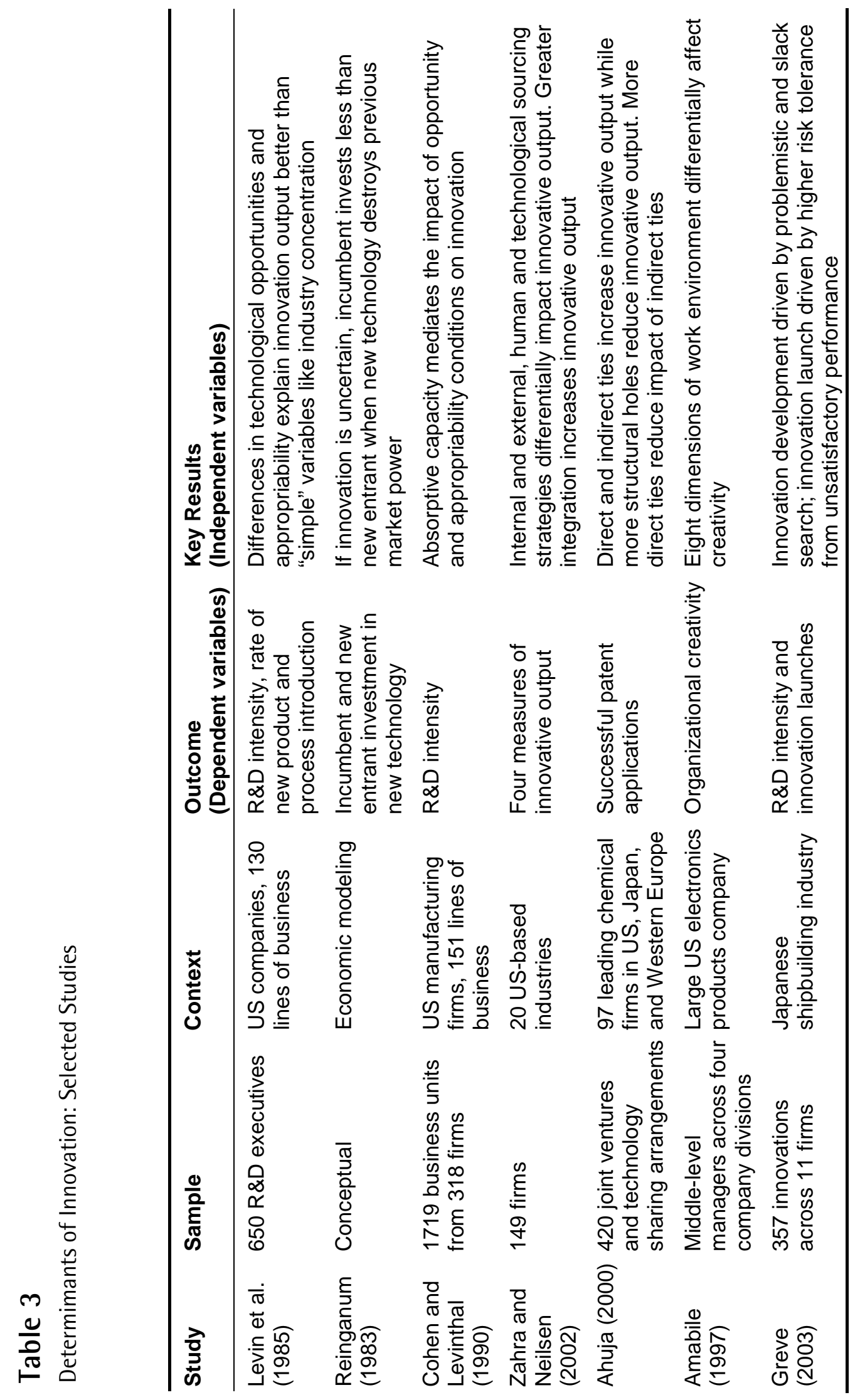


In their 1987 paper, Levin, Klevorick, Nelson and Winter also argued that inter-industry variations in innovative effort were best explained not by concentration, but by the underlying differences in technological opportunity and appropriability conditions (Levin et al., 1985; Levin, Klevorick, Nelson, and Winter, 1987). Thus variables such as concentration, regulation, intellectual property protection, size and growth, have an indirect effect on the amount of innovation observed, through their impact on technological opportunity and appropriability conditions.

\section{Drivers of Innovativeness: Learning and External Knowledge}

Early work examining the impact of external knowledge on differential firm innovativeness had sought to explain the "stylized fact ... that the number of innovations per dollar of R\&D decreases with firm size" (Knott, 2003: 697). Indeed the finding that R\&D productivity decreased with firm size was a common one (Cohen and Klepper, 1992; Cohen and Levin, 1989). However, in highlighting the different technological regimes facing large and small firms (Acs and Audretsch, 1988; Audretsch, 1991; Winter, 1984), these studies set the stage for a focus on the impact of the incorporation of external knowledge on firm innovation.

In an early study, Gort and Klepper (1982) posited, and found evidence that relative innovative advantage depended on the source of information leading to innovative activity. When information based on non-transferable experience in the market was an important input in generating innovative activity, then older firms would tend to have the advantage over new firms. However, when information outside the industry was a relatively important input in generating innovative activity, then new entrants would tend to have the innovative advantage over the incumbent firms.

Similarly, Knott (2003) highlighted the importance of asymmetric spillovers. She pointed out that if large or leading firms had superior knowledge, then spillovers from other firms would not be helpful to them. Consequently, their innovation would stem exclusively from their own efforts. In contrast, small or follower firms could gain knowledge both from their own investments as well as from spillovers from leading firms. As a result, their apparent innovation per R\&D dollar would be higher than that for large or leading firms. This conclusion is consistent with several authors who have suggested that small- and large-firm innovation are not independent. For instance, small firms may owe their innovative activity to former employees of large firms (Anton and Yao, 1995; Cassiman and Ueda, 2002; Klepper and Sleeper, 2002).

Cohen and Levinthal's seminal papers $(1989 ; 1990)$ introduced the concept of absorptive capacity, defined as "the ability of a firm to recognize the value of new, external information, assimilate it, and apply it to commercial ends" (1990: 128). They argued that absorptive capacity was largely a function of prior related knowledge (1989) and that it was critical to firms' innovative capabilities. Absorptive capacity is cumulative, domain-specific, and pathdependent (Cohen and Levinthal, 1994). Thus firms with greater absorptive capability in a given domain would be more innovative than others in that domain (Cohen and Levinthal, 1990). More recently, Zahra and George (2002) extended the concept of absorptive capacity, reconceptualizing it as a dynamic capability with both a potential and a realized component.

Internal knowledge is also an important input to the innovation process, and its integration with external knowledge is thus a critical determinant of innovativeness. Zahra and Nielsen (2002) found that innovative output developed with internal and external capabilities was 
affected by the effectiveness of the firm's mechanisms for integrating these knowledge sources. Similarly, Arora and Gambardella (1994) found support for the complementarity of internal and external know-how sourcing, while Cassiman and Veugelers (2002) found support for complementarity between the various innovation activities involved in these sourcing strategies. Thus firms combining different activities in their innovation strategy are expected to attain a higher degree of innovativeness than firms that focus on only one knowledge source.

In addition to this, recent studies suggest that different knowledge sources might be related to different types of innovative output. For example, Nicholls-Nixon and Woo (2003) find from their sample that while internal R\&D was positively associated with patent output, acquisition activity was positively related to the number of products based on new technologies, and the use of R\&D contracts and licenses was positively related to a reputation for technological expertise.

As a whole, this branch of work on the drivers of innovativeness has gathered momentum in recent times, and a number of insightful studies have shown how innovativeness also depends on variables such as network position (e.g. Ahuja, 2000), technological and market relatedness of merging firms (e.g. Ahuja and Katila, 2001; Cassiman, Colombo, Garrone, and Veugelers, 2003), alignment between governance decisions and the degree of contractual hazards (Leiblein, Reuer, and Dalsace, 2002), and the impact of process management on various types of innovative output (Benner and Tushman, 2002, 2003). A major contribution of this young stream of literature is that it highlights the fact that innovativeness is dependent on a firm's ability to leverage external knowledge, integrating it with its internal knowledge sources.

\section{Drivers of Innovativeness: Organizational Factors}

The second branch of innovativeness studies has identified three organizational variables that drive differential firm innovativeness, namely: the creativity of organizational members, the management of the innovation process, and the presence of organizational slack. Individual creativity introduces greater variation into the organization, increasing its innovative output, while competent management of the innovation process removes obstacles that might slow down the flow of innovations, efficiently integrating the innovative efforts of organizational members. Finally, it is has been suggested that spare organizational resources allow experimentation and less strict performance monitoring, leading to increased innovation.

Many authors have considered the improvement of an organization's innovativeness as a question of how to "unlock the ideas and creativity of its employees" (Kim and Mauborgne, 1999: 51). Amabile (1997) for example, stresses that in addition to expertise and creative thinking, employee creativity is also a function of task motivation, and thus motivation is an important driver of organizational innovativeness. Among other things, such motivation requires a concise and compelling articulation of the value of innovation, an orientation away from the status quo, and the activation of an offensive leadership strategy aimed at the future, rather than simply trying to protect an organization's past (Amabile, 1988).

Employee creativity is also related to task organization, management style, and organizational culture. One typical finding in this line is that creativity is fostered by the use of small autonomous units or teams focusing on a common business or product goal (Kim and Mauborgne, 1999). In addition, teams with members with diverse skills, backgrounds, and perspectives are more conducive to higher levels of creativity (Amabile, 1997; Kanter, 1996; Kim and Mauborgne, 1999). Finally, creativity has been found to thrive in the presence of a 
corporate culture conducive to willing collaboration where managers go beyond a focus on fair outcomes to a focus on fair process (Kim and Mauborgne, 1999).

A second organizational factor driving innovativeness is the competent management of the innovation process. As Christiansen (2000) emphasizes, management structures, systems and practices can cause delays in the innovation process, creating roadblocks for the flow of innovations. Senior managers can improve innovativeness by enhancing systems, structures and practices at three levels, namely: the individual innovation project, the project management system, and business-level strategy (Christiansen, 2000; Duelli and Hültenschmidt, 2002; Kandybin and Kihn, 2004). At the project level, efficiency depends on project setup, supervision, participation, mentoring/consulting, and operational control. At the level of the project management system, attention to idea generation, laboratory management, funding systems, project structure, and project management methods affect innovative output. Finally, the way business systems are managed in terms of strategy, structure, and people has a decisive impact on the level of organizational innovativeness (ibid.).

A third theme in organizational innovativeness is related to the role played by organizational slack. Cyert and March (1963) proposed that organizational slack, rather than "necessity" bred innovation. According to them, "the difference between the payments required to maintain the organization and the resources obtained from the environment by the coalition ... provides a source of funds for innovations that would not be approved in the face of scarcity" (Cyert and March, 1963: 278-279). Organizations with spare time and spare resources have greater opportunities for experimentation and less strict performance monitoring and so should have the resources and managerial patience needed to innovate.

In one of the few empirical tests of this hypothesis, Greve (2003) distinguishes between absorbed slack, unabsorbed slack, and potential slack. He finds that while absorbed slack is related to increased innovativeness, his sample shows no effect for the other two types of slack. Similarly, 0'Brien (2003) argues that financial slack is necessary for innovativeness for three primary reasons. Firstly, cash flow volatility can jeopardize continuous investments in R\&D. Secondly, financial slack can help ensure that the firm has the financial resources required to launch new products as soon as they are ready; and finally, sufficient financial slack can assist firms in making the acquisitions they deem necessary to source knowledge for increased innovativeness (ibid: 419-420). Operationalizing financial slack as a low leverage ratio, he finds support for the position that higher innovativeness (intense investment in R\&D) is related to higher financial slack.

\section{Innovation Outcomes vs. Performance Outcomes}

In summary, we find that the literature provides a relatively clear theoretical account of the antecedents of TI. The amount of innovation observed among a focal group of firms is dependent on underlying technological opportunity and appropriability conditions. These latter in turn depend on factors such as industry concentration, growth, RetD expenditure, firm size, intellectual property protection, regulation, and the current technological and economical regime. At the same time however, innovativeness differs across individual firms facing similar opportunity and appropriability conditions. Such differences are explained by knowledge characteristics like absorptive capacity, technology sourcing strategies, integration capabilities, and network position; as well as by organizational factors such as member creativity, process management, and the presence of organizational slack. As mentioned earlier, these relationships are summarized in Figure 2. 
Nevertheless, much of this literature exhibits an underlying assumption that individual innovations are inherently valuable. Theoretically however, individual innovations can be more or less successful, and empirically only a small proportion of innovations are profitable (Andrew and Sirkin, 2003; Rothaermel, 2001). Thus firms following prescriptions for increasing their innovativeness could conceivably find themselves generating a stream of worthless innovations. Therefore, this literature on innovation outcomes does not seem to provide a basis for an a priori optimistic view of the impact of TI on performance; nor does it provide much insight into the contingencies that could determine the performance of individual innovations.

Nonetheless, the findings on drivers of innovation form a basis for prescriptions regarding policies to foster industrial innovation and competitiveness. Similarly, the findings on drivers of innovativeness identify levers managers could act on to increase innovative output. However, on the basis of these studies alone, such prescriptions would have to be made with the assumption that the value of a greater number of profitable innovations outweighs the costs of a greater number of failed innovations.

\section{Determinants of Technical Outcomes: Dynamics of Technological Change}

Studies relating to the technical outcomes of TI have highlighted determinants of the complex process by which TI leads to technological change. Technical advances on their own do not directly cause technological change; rather, new technologies enter the industry at some time or the other via the TI of one or more firms. If a TI is sufficiently superior to products embodying previous technology, (in the absence of restraining political or social forces) it can trigger a substitution of the core technologies used by industry participants to satisfy customer needs (Cooper and Schendel, 1976; Foster, 1986). This consequent technological change can be considered a technical outcome of TI.

Two broad streams of work have isolated the determinants of the technical outcomes of TI. The first has focused on the drivers of the process by which TI leads to technological change. Studies in this stream have looked at the interaction and impact of market opportunities and technological effort on the process of technological change. They have also highlighted how design decisions and customer choices determine the technical outcomes of TI.

A second stream of studies has investigated the patterns of technological change. This work suggests that technological change exhibits a cyclical pattern which is repeated over time. As firms introduce technological innovations over time, the consequent technological substitutions display long periods of incremental improvement punctuated by sharp improvements in the industry's price/performance frontier. These latter are then followed by periods of technological ferment which end with the appearance of a "dominant design."

The seminal studies in both streams are based on longitudinal multi-industry data on the dynamics of technological change, although some other influential studies derive their frameworks from an inductive analysis of in-depth case studies. Figure 3 summarizes the findings of both streams on the drivers and patterns of technological change, while selected studies are summarized in Table 4. 


\section{Drivers of Technological Change}

Early answers to the question of the drivers of technological change (TC) revolved around two basic poles: the so-called "demand-pull" theories on the one hand, and the so-called "technology-push" theories on the other hand. Demand-pull theories pointed to market opportunities as the main determinants of the process through which TI led to TC. In this view, the causal prime mover of TC is the recognition of needs by productive units in the market, followed by attempts to fulfill those needs through technological innovation (Mowery and Rosenberg, 1979). Therefore, market signals direct innovative activity and TC. Proponents of the technology-push theories argued, on the other hand, that TC was autonomous or quasiautonomous with respect to short-run changes in the economic environment (Pavitt and Soete, 1980). Underlining supply-side factors in TC, they pointed to the increasing role of scientific inputs in the innovative process, the increased complexity of R\&D (making it unlikely that it could be a prompt innovative answer to market signals), a significant correlation between R\&D and innovative output, and the intrinsically uncertain nature of the innovative process (ibid.).

\section{Figure 3}

Technical Outcomes of Technological Innovation

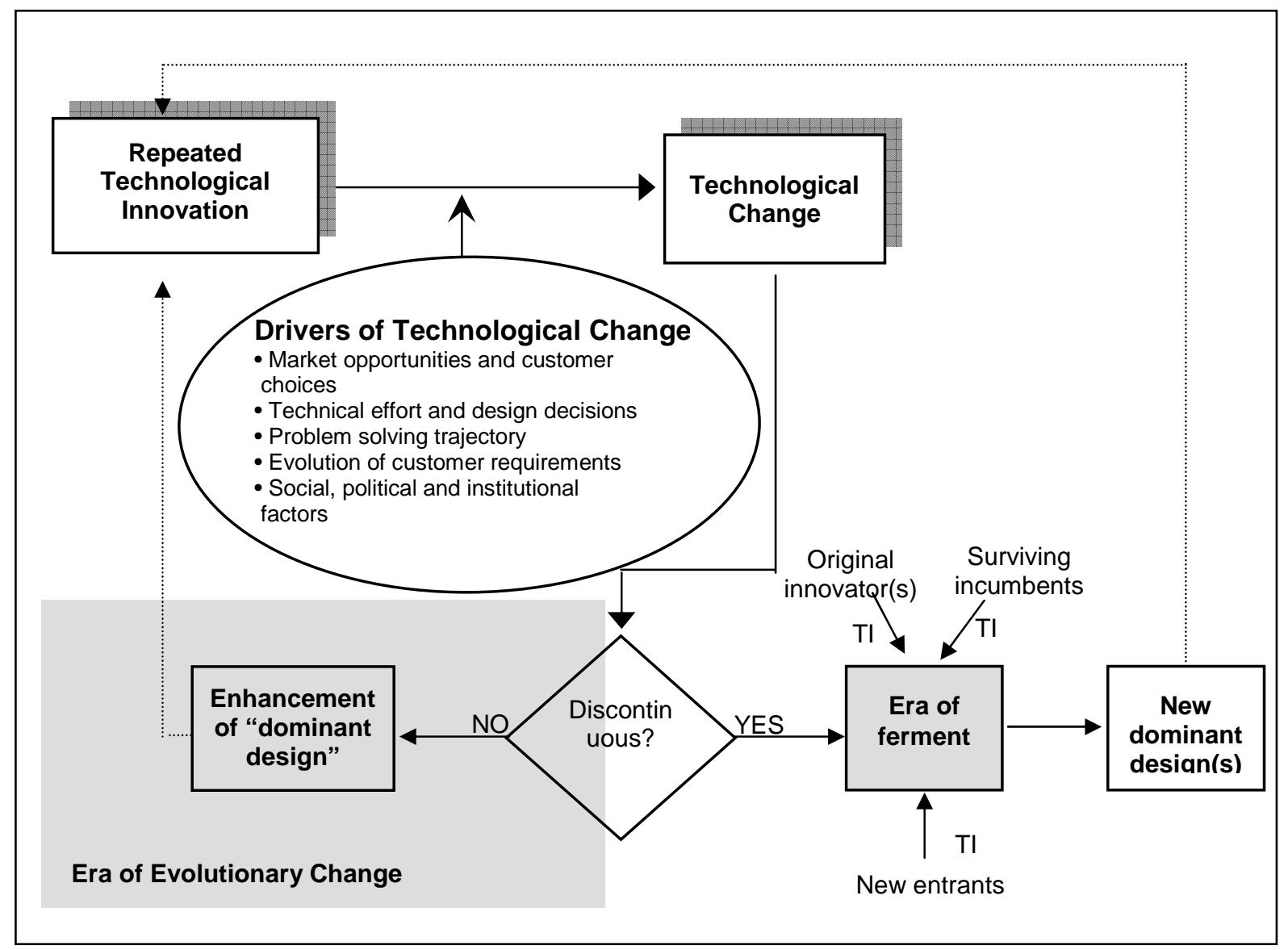


Dosi (1982) was one of the first to point out the flaws inherent in both extremes. He pointed out that on the one hand "demand-pull" theories see TC as a passive, "mechanical" reaction to market conditions. They are incapable of "defining the why and when of certain technological developments instead of others and of a certain timing instead of others" (ibid: 150), and they neglect changes over time in inventive capability that do not bear any direct relationship to changing market conditions. On the other hand, "technology-push" theories are flawed as well because they present technical progress as "given by God, scientists, and engineers" (ibid: 151); ignoring the obvious impact of economic factors in shaping the direction of the innovative process.

Dosi sought to harmonize the two extremes by introducing the concepts of "technological paradigms" and "technological trajectories." Technological paradigms are "an 'outlook', a set of procedures, a definition of the 'relevant' problems and of the specific knowledge related to their solution" (ibid: 148). Technological paradigms in technology are analogical to research programs in science, and determine the technological problems to be solved, the scientific principles to be applied, and the material technologies to be used (Dosi, 1984). At the same time though, these paradigms also define technological trajectories, which are "the direction of advance within a technological paradigm" (Dosi, 1982: 148). In other words, the technological trajectory is the pattern of problem-solving within the established technological paradigm, similar to Nelson and Winter's (1982) "natural trajectories" of technological progress.

Hence both technological and market factors drive the process of TC. Although the established paradigm is most influential on TC in the short run, in the long run new technological paradigms can arise from the interplay between scientific advances, economic factors, customer requirements, institutional variables, and unsolved difficulties in established technological paths (Dosi, 1982). Consequently, while the current technological paradigm greatly influences the technological trajectory, a more complex set of interactions determines the appearance of a new technological paradigm.

In a similar vein, Sahal's $(1981 ; 1985)$ explanation focuses on "technological guideposts" and "innovation avenues." In this system, similar to Dosi's, a technological guidepost is a "pattern of design" that charts the course of innovative activity (Sahal, 1985: 71), while TC occurs along innovation avenues "that designate various distinct pathways of evolution" (ibid.).

Clark (1985) deepened the analysis of the interaction between technological design decisions and customer choices in the process through which TI leads to TC. As an industry's technology evolves, "the pattern of innovation, the kinds of design changes introduced and their timing and sequence, not only depend on the technical alternatives but on the interaction between the internal logic of the product and the evolution of customer requirements" (Clark, 1985: 236). In other words, on the one hand, observed patterns of TC depend on a sequence of design decisions related to the technical agenda, problems to be solved, cumulative experience, exploration of alternative technical options, and a continual refinement of current designs (McEvily and Chakravarthy, 2002). However, on the other hand these design decisions are also related to "the formation of concepts that underlie customer choice" (Clark, 1985: 241).

Experience with new technological products, problem solving at the customer end, new uses customers discover for products, and emerging customer needs not only affect technical development (as in market-pull theories), but are also influenced by design choices. For example, early customer automobile purchase decisions were framed in terms of a choice between a "horseless carriage" and a "carriage with a horse." However, experience with the new 
product, as well as continued evolution of the initial product design led to the evolution of the concept from "horseless carriage" to "automobile," described by a "new" set of attributes such as speed, mobility, endurance, payload, etc., and a "new" set of variants like "roadster," "touring car," and "coupe" (ibid: 245).

\section{Patterns of Technological Change}

The work of Abernathy and Utterback (Abernathy and Utterback, 1978; Suarez and Utterback, 1995), along with that of Tushman and Anderson (Anderson and Tushman, 1990; Tushman and Anderson, 1986, 1997) has greatly influenced research on the patterns of technological change.

Extending studies on drivers of TC (David, 1985; Dosi, 1984; Nelson and Winter, 1982; Sahal, 1985; Utterback and Abernathy, 1975), Anderson and Tushman held that technological change in many industries is a cyclical evolutionary process in which "the core technology of an industry evolves through long periods of incremental change punctuated by technological discontinuities" and the "emergence of a dominant design" (1990: 606). Thus each cycle is composed of two "eras" and two "punctuation points," as described below.

In the first stage, "technological change is a bit-by-bit, cumulative process until it is punctuated by a major advance" (Tushman and Anderson, 1986: 441). In this "era of incremental change" (Anderson and Tushman, 1990: 606) there are continual improvements to technology within the same technological paradigm, "through the interaction of many organizations stimulated by the prospect of economic returns" (ibid.). Variation in this era is driven by elaboration of the established "dominant design" and the competitive focus shifts from higher performance to lower cost (Abernathy and Utterback, 1978). 


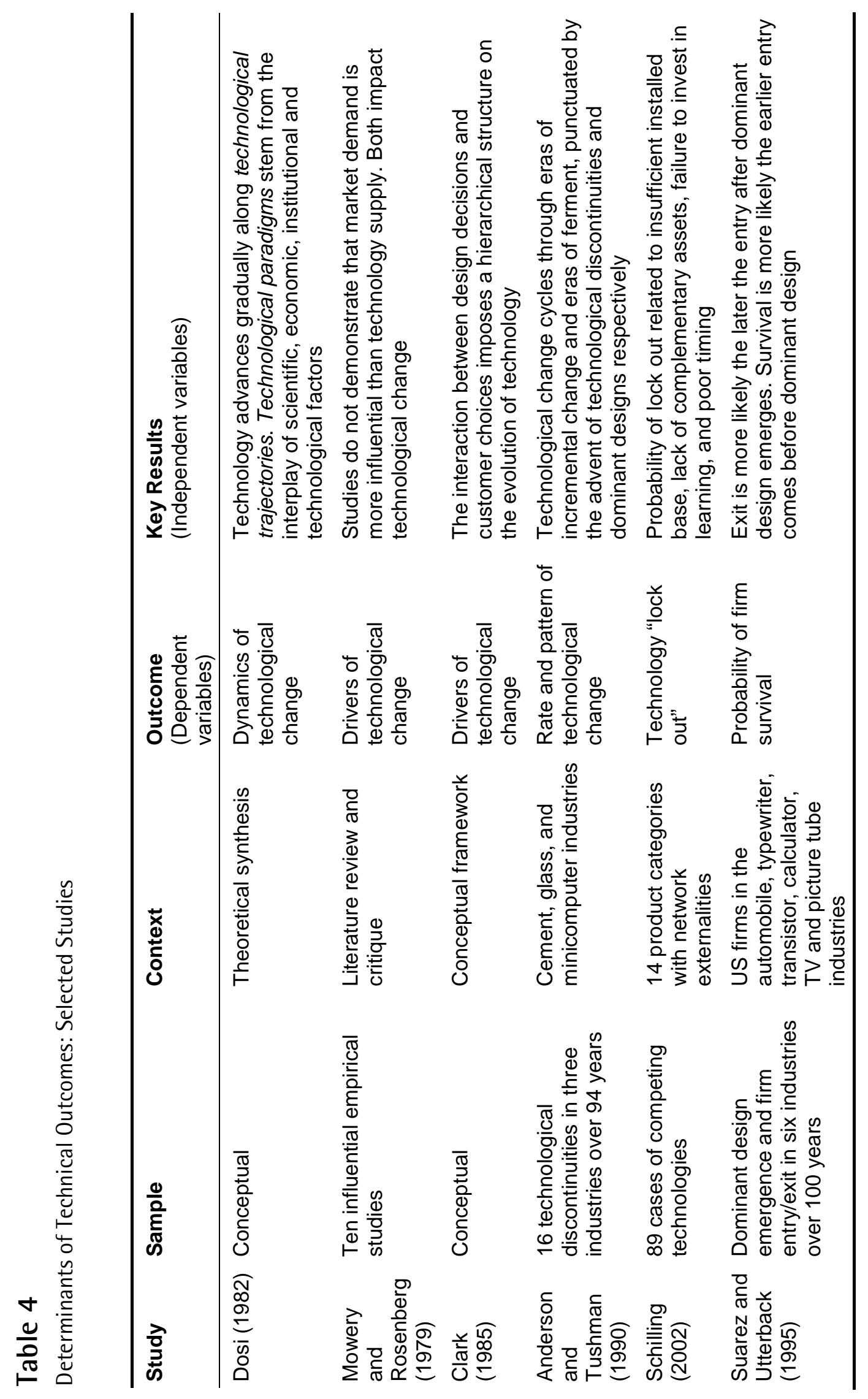


Nevertheless, this era is characterized by "advances in the technology frontier that advance the state of the art ... sometimes considerably" (Anderson and Tushman, 1990: 609) within the same technological paradigm. As such, in Anderson and Tushman's scheme, the "era of incremental change" can refer to either "incremental" or "considerable" improvements. Lawless and Anderson (1996) rectify this ambiguity by proposing the concept of "generational" TC, which is "a major advance within a technological regime" (ibid: 1185). Thus the major characteristic of this era of evolutionary ${ }^{3}$ change is the cumulative enhancement of the current dominant design (sometimes incremental and sometimes generational) within the same technological paradigm.

The era of evolutionary change is ended by the appearance of a "technological discontinuity": a sharp improvement in the industry's price performance frontier associated with the emergence of a new technological paradigm (Anderson and Tushman, 1990; Tushman and Anderson, 1986), which introduces an era of intense technological variation. "A revolutionary innovation is crude and experimental when introduced, but it ushers in an era of experimentation as organizations struggle to absorb (or destroy) the innovative technology" (Anderson and Tushman, 1990: 610-611). This "era of ferment" (ibid.) is characterized by competition between alternative technologies within the new paradigm, as well as by competition with old technologies, which typically experience significant improvement, in reaction to the new technological threat (Cooper and Schendel, 1976).

Competition between rival technologies in the era of ferment is a highly complex process whose result cannot be predicted ahead of time (Tegarden, Hatfield, and Echols, 1999). The technical outcome is a function of several factors, such as user preferences and producer market power (Anderson and Tushman, 1990), complementary assets controlled by competitors, industry regulation or government intervention (Suarez and Utterback, 1995), and the presence of "increased returns to adoption" (Arthur, 2001) among the competing technologies (Katz and Shapiro, 1985, 1986; Schilling, 2002).

The case of competition among technologies exhibiting increasing returns on adoption has been especially studied in the strategic management and economic literature. Increasing returns on adoption could come from many sources, such as learning by using, network externalities, scale economies in production (positive feedback), informational increasing returns, and technological interrelatedness (Arthur, 2001; Katz and Shapiro, 1985, 1986). The selection process in this case is potentially "inefficient" in an economic sense because the "winning" technology might not be the socially optimal one (Arthur, 2001). Although it is difficult to say which technology will win ex ante, it is not impossible to predict which technologies will end up losing or being "locked out" (Schilling, 2002). Factors that might lead to "lockout" are a relatively small installed base, relatively poor availability of complementary goods, a failure to invest in learning, and poor entry timing (ibid.).

Finally, in mass markets with relatively homogenous customer tastes, or where industry output is a high volume assembled or manufactured product, the era of ferment may end with convergence on a "dominant design" (Utterback and Abernathy, 1975), which is "a specific path along a design hierarchy, which establishes primacy among competing design paths" (Utterback

\footnotetext{
${ }^{2}$ Emphasis added.

${ }^{3}$ We introduce this term to stress the fact that technological change in this era can be incremental or generational, as long as it remains within the same technological paradigm.
} 
and Suarez, 1993: 47). ${ }^{4}$ However, in technology markets characterized by increasing returns on adoption, the outcome might be the adoption of one or more of the competing technologies, depending on a host of factors such as whether or not technologies are "sponsored" (backed by strategic investment), their future cost advantage (Katz and Shapiro, 1986), the availability of complementary products, installed base, entry timing (Schilling, 2002), learning effects, production scale effects, and lock-in (Arthur, 2001). With convergence on a dominant design(s), the industry returns to an era of evolutionary progress once again (Christensen et al., 1998; Suarez and Utterback, 1995; Utterback and Suarez, 1993), closing the cycle of TC.

\section{Technical Outcomes vs. Performance Outcomes}

In summary then, we can identify a relatively mature and well-developed literature on the technical outcomes of technological innovation. These analyses show the emergence of technological change from TI to be partially determined by the path-dependent technical trajectory followed in problem solving, as well as by the overall technological paradigm in force. Technological evolution is further co-determined by the development of customer understanding and choice, under the influence of social and institutional factors. The overall process, though, has been found to be markedly patterned across several industries, exhibiting eras of evolutionary progress and eras of disruptive change, punctuated by "technological discontinuities" and the emergence of a "dominant design" respectively.

Nevertheless, these studies do not seem to justify an overly optimistic view of the performance outcome of TI. The distinction between technical and performance outcomes stressed in this article is important because a favorable technical outcome will not necessarily lead to improved firm performance. In this line, work by Tegarden et al (1999) has highlighted the importance of other variables, such as entry timing (Mitchell, 1989, 1991), integration (Iansiti, McFarlan, and Westerman, 2003), and flexibility to switch to a different technology, as being to some extent independent of the eventual technology outcomes. Other work (e.g. Shamsie, Phelps, and Kuperman, 2004) suggests late-mover advantages as a reason why a focus on the technical outcome alone could lead to disappointing performance outcomes.

Nonetheless, these studies do provide insights useful for the study of performance outcomes. On the one hand, they underline the fact that technological change, although an industry-level phenomenon, is not exogenously given with respect to the actions of industry participants, but is partially shaped by their innovative efforts. TI in effect, is both a "response to incentives" created by industry conditions and a "shaper" of those conditions (Porter, 1985: 195). On the other hand, they suggest that the performance outcome of a technological innovation may be contingent on the technological situation in an industry at a given point in time. Thus an understanding of the processes by which TI leads to technological change should be important for understanding the determinants of the performance outcomes of TI.

\footnotetext{
${ }^{4}$ McEvily and Chakravarthy (2002: 286) prefer the term "normal configuration," as the term "dominant design" has sometimes been taken to imply "that the same [product] configuration is adopted by all firms."
} 


\section{Determinants of Perfomance Outcomes of Technological Change}

Whereas studies of innovation outcomes and technical outcomes of TI span several decades, studies seeking to explain firm performance outcomes of technological change are more recent. Most of the major studies started to appear at the end of the 1980s, promoted by strategic management scholars' interest in firm-level performance outcomes.

A lot of the early work in this area focused on explaining why technological change (TC) often caused the failure of hitherto successful firms. They traced inferior incumbent performance to the impact of TC on firm capabilities, as well as to insufficient investment in new technologies; both mediated by the retention of critical complementary assets. More recent studies, however, have identified and sought to explain differential performance among firms facing the same TC. They have focused on the impact of differential firm approaches to technology sourcing, collaborative alliances, and product line strategies amongst other factors. The major findings of both streams are summarized in Figure 4, while Table 5 summarizes some selected studies.

It is pertinent to note here that many followers of the literature on innovation might inappropriately identify this set of studies as focusing on the performance outcomes of technological innovation. As we argued earlier, while technological innovation might be actively pursued by individual firms, technological change is more or less passively experienced by all firms in an industry. Thus this set of studies, which focuses on the effects that the substitution of technologies used to satisfy customer needs has on firm fortunes, is classified here as focusing on the performance outcomes of technological change.

\section{Figure 4}

Performance Outcomes of Technological Change

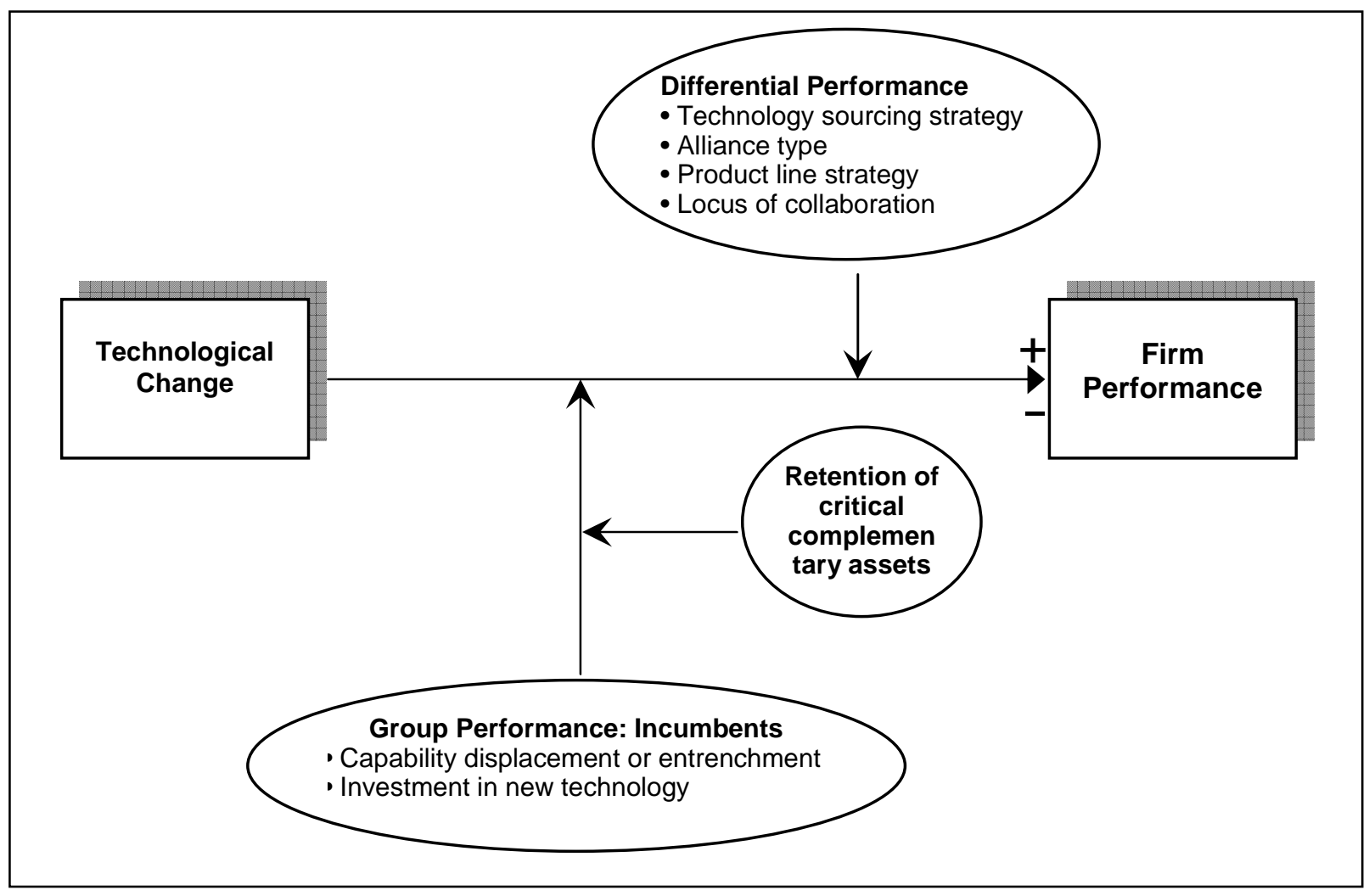




\section{Technological Change and Inferior Firm Performance}

It was observed early on that "radical" technological change often led to the demise of industry incumbents (Abernathy and Utterback, 1978; Cooper and Schendel, 1976; Foster, 1986; Utterback and Abernathy, 1975). Hence much of the initial work in this stream focused on explaining why TC seemed to worsen the performance of "incumbent" firms, sometimes identified in terms of size, and other times in terms of previous market or financial performance (Christensen and Bower, 1996; Henderson and Clark, 1990; Tripsas, 1997). The various explanations that have been given can be grouped into three: the impact of technological change on firm capabilities, the consequences of firm investment decisions, and the moderating effect of critical complementary assets.

Firm capabilities. New technologies resulting from technological change may require capabilities different from those historically possessed by incumbents, or previous capabilities may retain their importance. In the first case, or capability-displacing TC, the relevance of historical incumbent capabilities is reduced in favor of a new set of capabilities (Abernathy and Clark, 1985; Clark, 1987). However in the second case, or capability-entrenching TC, new technologies continue to require previous capabilities, thus "entrenching" their position (Clark, 1987: 63) within firms.

As could be expected, capability-entrenching TC has been found to favor incumbents (Cooper and Schendel, 1976; Rosenbloom, 2000; Rothaermel, 2001), as the market "rewards" those activities and knowledge bases in which they are already proficient (Hill and Rothaermel, 2003). However, capability-displacing TC has generally been found to prejudice the performance positions of incumbents. In the face of capability-displacing TC, incumbents are either unable to exploit the new technology, or their investments produce poorer results compared to those of new entrants (Christensen et al., 1998; Henderson, 1993; Henderson and Clark, 1990; Tripsas, 1997). Economic, organizational, and strategic factors deny them the flexibility required to react adequately to the change, leading to poorer performance (Hill and Rothaermel, 2003).

Henderson and Clark (1990) for example, showed that the displacement of firms' "architectural knowledge" is especially lethal. Firm knowledge relating to linkages between product components tends to become embedded in structures and information-processing procedures that are difficult to change. Thus when this architectural knowledge gets displaced, firms find it hard to respond adequately (ibid). Nagarajan and Mitchell (1998) also highlight the importance of the dimensions along which incumbent capabilities are entrenched or displaced. They suggest that TC will have different outcomes depending on whether capabilities are displaced in "core" activities ("encompassing technological change") or in "complementary" activities (“complementary technological change”).

Finally, Afuah (2000) drew attention to the fact that firm performance could still suffer if TC entrenched incumbent capabilities, but displaced the capabilities of their "co-opetitors" (suppliers, customers, and complementors). He found support for the hypothesis that TC which displaces the capabilities of a firm's suppliers or customers leads to poorer performance for the firm in question. He also suggested that the closer such firms are to their suppliers (operationalized as degree of backward integration), the poorer their performance will be. 


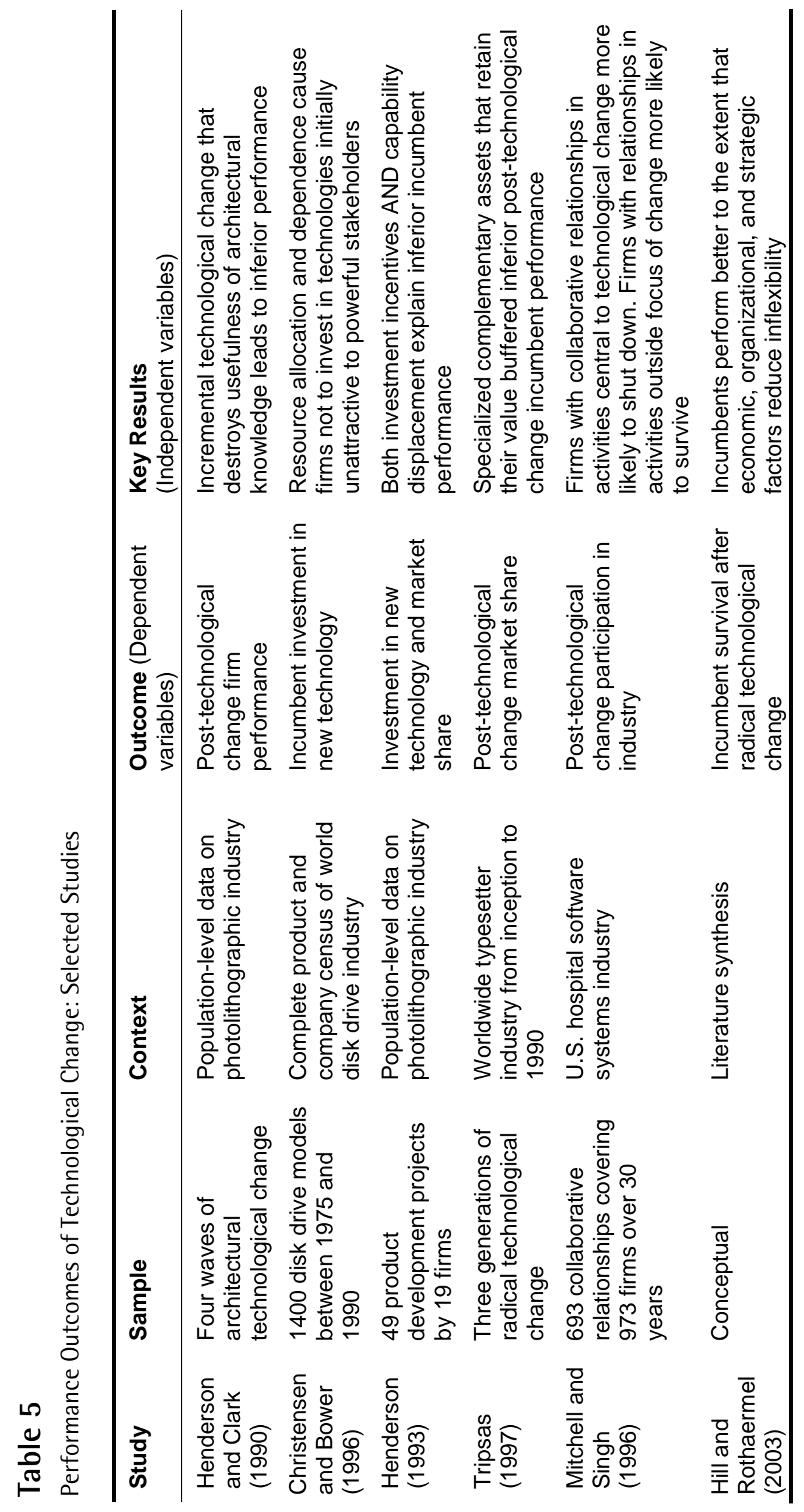


Incumbent investment. Another set of studies traces the roots of incumbent demise to a failure to invest in new technology until it is too late. Though apparently a straightforward explanation, varying causal mechanisms have been put forward to explain this phenomenon. One group of studies mentioned earlier suggests that incumbents might not invest in a new technology for fear of destroying current market power and demand for current products (Gilbert and Newbery, 1984b; Henderson, 1993; Reinganum, 1983, 1984). Thus if subsequent TC causes a switch to the new technology, incumbent firms would find themselves in a disadvantaged position.

Arend (1999) presents an alternative explanation focusing on the dynamics of oligopoly. In his model, TC is exogenous and perfectly foreseeable, such that incumbents could implement it and thus block later entrants if they wished to. However, if the new technology implies a short-run cost disadvantage relative to current competitors, in the absence of collusion it is possible that none of the incumbents will invest in the new technology, leaving them open to the adverse impact of new entrants in the future.

A different explanation for failure to invest comes from Christensen and Bower (Christensen, 1997; Christensen and Bower, 1996). Combining resource allocation (Bower, 1970) and resource dependence (Pfeffer and Salancik, 1978) theories, they argue that resources in corporations get allocated to projects targeting the requirements of powerful customers. Incumbents thus will not invest in "inferior" technologies that exhibit a price/performance ratio unattractive to their valuable customers. However, the rate of technological progress can cause incumbents' technology to exceed customer requirements, while simultaneously making previously "inferior" technologies now attractive to their customers (Christensen and Bower, 1996). Thus since they had previously not invested, (because the technology was not initially attractive to their valuable customers), they would find themselves in a disadvantaged position (Christensen, 1997).

Finally, another set of studies underlines the fact that firms are "embedded within a value network of suppliers, customers, investors, complementary product providers, communities, and so on, to which the firm has made strategic commitments" (Hill and Rothaermel, 2003: 261). As Ghemawat (1991) emphasizes, "strategic" decisions, which "commit" a firm to a particular course of action or bundle of resources over the medium to long term, bring along with them a certain degree of inflexibility. In addition, a web of implicit and explicit social commitments to employees, customers, and communities can also impede adaptation (Rosenbloom, 2000; Sull, Tedlow, and Rosenbloom, 1997). Hence incumbents may find themselves unable to make the investments necessary to participate effectively in the new technological regime, as a result of prior commitments.

Complementary assets. A third factor, the continued importance of critical complementary assets controlled by incumbents, has been shown to moderate the effect of the previous two on performance. Tripsas (1997) found that when specialized complementary assets (Teece, 1987) unavailable to new entrants retained their value after capability-displacing TC, incumbents maintained their market positions even though the technical performance of their products proved to be significantly inferior to that of the new entrants. Similarly, Rothaermel (2001) found that incumbents whose downstream complementary assets retained their value after TC, entered into alliances with new entrants to access the new upstream technology, in exchange for access to their downstream assets. In other words, these findings suggest that even if incumbents do not have the required capabilities to participate effectively in the new 
technology, any important complementary assets that "luckily" retain their value after the TC will temper the negative effects of capability-displacing TC.

\section{Technological Change and Differential Firm Performance}

Recent work on the determinants of performance outcomes of TC has increasingly focused on differential firm effects. Tripsas suggests that the most serious limitation of the earlier work we have been considering is "its treatment of incumbents as a class of firms without distinguishing between individual firms within that class. There is great variation in the performance of incumbent firms, and understanding that variation is crucial" (Tripsas, 1997: 140). This is further underlined by Hill and Rothaermel's (2003: 257) assertion that the counterexamples to the generalized predictions (e.g. Ahuja and Lampert, 2001; Leifer et al., 2000; Methe, Swaminathan, Mitchell, and Toyama, 1997; Rothaermel, 2001) are too many to be ignored.

An additional reason for the growing focus on differential firm effects is the existence of conflicting group-level findings in the literature. For example while Tripsas (1997) finds that incumbents produced technically inferior products on investing in a capability-displacing technology, Christensen and Bower (1996) find that incumbents led the way, even in capabilitydisplacing technologies, as long as their important customers valued them highly. A number of recent studies have begun the attempt to tease apart such interacting effects, extending research on the performance outcomes of TC in two important directions.

Differential incumbent reactions. Firstly, researchers have begun to focus on differential incumbent reactions to TC. Thus Nagarajan and Mitchell (1998) studied incumbents' technology sourcing strategies in the face of TC. They predicted the technology acquisition strategy of incumbents (equity/non-equity alliances or internal RetD) in terms of how capability-displacing TC affects "core" and "complementary" firm activities in manufactured products.

Building on Nagarajan and Mitchell's work, Nicholls-Nixon and Woo (2003) suggest that such differential approaches to technology sourcing, are related to differing levels of innovative output across firms facing the same capability-displacing TC. A related study by Rothaermel (2001) showed that incumbents might react by forming alliances with new entrants when critical downstream complementary assets that they control retain their value after TC. Distinguishing between exploration alliances (aimed at learning the new upstream technology) and exploitation alliances (aimed at leveraging the downstream complementary assets), he found that incumbents that focused on exploiting complementary assets outperformed those that focused on exploring the new technology (in terms of new products introduced). Thus these studies suggest that differential incumbent performance after TC might be related to the "fitness" of the different capability sourcing strategies they use.

Differential firm strategy. Beyond a focus on incumbent reactions, Jones (2003) finds that product line strategy and product platform strategy explain additional variation in performance after capability-displacing TC, controlling for incumbent/entrant-related factors. Specifically he shows that variation in overall product introduction rates and longevity, as well as rates of platform and derivative introduction and longevity, significantly increase his model's explanatory power. His work thus suggests that a focus on new variables could help to identify other drivers of differential post-TC performance.

Mitchell and Singh (1996) take a different approach, analyzing the impact of pre-TC collaborative relationships on post-TC performance. They find that firms using collaborative relationships in activities affected by discontinuous TC perform worse after the TC, while firms 
with collaborative relationships in activities not central to the TC have improved post-TC performance. They thus suggest that while collaborative relationships hinder the flexibility of the former, for the latter they provide useful help for navigating the TC.

A final perspective on TC and differential firm performance comes from Lawless and Anderson (1996) who study the indirect impact of generational $\mathrm{TC}^{5}$ on firm performance. They suggest that successive generational TC leads to increased environmental complexity as previous technologies remain in the market, and firms have a broad range of opportunities to be generalists or to specialize in a subset of the available technologies. This is accompanied by an evolution of niches or "firm positions in the marketplace" (ibid: 1186). They find that performance depends on firm strategies that differentiate them within their own niches, and not across niches. They also find that changing niches confers a short-term penalty, and that strong performers adopted new technology quickly without changing niches.

\section{Performance Outcomes of Technological Change}

To sum up, the literature reviewed here gives a clear account of some of the determinants of the performance outcomes of technological change. It demonstrates that TC often has a negative impact on the performance of previously successful firms, either because of new technology that requires capabilities different from those they have historically possessed, or because they do not invest in technology that later becomes dominant. This effect is tempered if they control other complementary assets required to exploit new technology successfully.

However, recent work has shown that the same TC can have differential impacts on the post-TC performance of incumbents, as a result of factors such as technology sourcing and collaborative strategies. Other scholars also suggest that variables cutting across both incumbents and entrants can help explain post-TC firm performance. Thus both pre-TC strategic choices, such as inter-firm collaboration, and post-TC variables such as product line and product platform strategies, can influence the impact of TC on firm performance.

Future research in this stream will need to provide more robust explanations of differential post-TC firm performance. On the one hand this might require the identification of other firmand/or network-level strategies that better explain post-TC performance. On the other hand, there is a need for empirical work that can help to determine the relative efficacy of competing strategies put forward by different scholars. ${ }^{6}$

Nevertheless, the findings of this important stream of work do not provide an account of the determinants of the performance outcomes of firm-level technological innovation. The underlying concern of these studies has been more about firm strategies for coping with the inexorable march of technological change, and less about the possible outcomes of individual technological innovations. Thus these studies do not seem to provide a basis for an assumption that technological innovation will improve firm performance.

\footnotetext{
${ }^{5}$ A substantial technological advance within the same technological paradigm.

${ }^{6}$ For example, while Christensen (1997) advocates spinning off an independent firm to cope with technological change, Iansiti et al. (2003) advise as much integration as possible to leverage existing firm assets.
} 
Having said that, it is important to remember, as we pointed out in the previous section, that technological innovation is intimately related to technological change. Indeed Cooper and Schendel (1976) indicate that TI is a common firm reaction in the face of TC. Thus the increased attention to the determinants of the performance outcome of TI advocated in this paper could shed more light on performance outcomes of TC as well.

\section{Determinants of Performance Outcomes of Technological Innovation}

Surprisingly few studies have focused on the determinants of the performance outcome of technological innovation. While a lot of work has looked at determinants of innovativeness, much less light has been shone on the innovation-level contingencies that determine the success or failure of individual innovations (Li and Atuahene-Gima, 2001). Similarly, while a good number of studies have investigated technical outcomes, few have considered how and when technical aspects affect performance. Nevertheless, some important contributions to knowledge on determinants of the performance outcome of TI have staked out the territory, and indicate directions for future work.

In the next section, we review some of these studies and characterize their findings on factors that affect the impact of technological innovation on firm performance. We then synthesize these with findings from previous sections, to give a comprehensive picture of what we know about the outcomes of technological innovation. Finally we conclude, reiterating the need for an increased focus on the determinants of the performance outcome of technological innovation, and offering possible avenues for building on the existing knowledge in this regard.

\section{When Does Technological Innovation Improve Performance?}

An important early contribution comes from Teece's seminal 1986 paper that sought to explain why customers, imitators, and other industry participants often benefited from TI, whereas the firm that introduced it did not (Teece, 1987). He showed that under a "weak appropriability regime," most profits go to the owners of specialized complementary assets required for commercializing an innovation. The strength of the appropriability regime is a function of the legal mechanisms available to protect innovations, such as patents, trade secrets, trademarks, and copyrights (Teece, 1987); as well as the knowledge characteristics of the innovation: whether the knowledge is tacit or codified, observable or non-observable in use, and whether it requires tangible assets or not (Teece, 2003). In weak appropriability regimes therefore, innovating firms need to have recourse to strategic action (by carefully choosing firm boundaries) to protect their returns on TI.

A different set of variables was highlighted by Banbury and Mitchell's study, which considered how the timing of TI influenced its impact on performance. In focusing on innovations that "succeed in the market as a class of goods," they sought to "differentiate between the success of an innovation as a class of goods and the success of specific firms that introduce products that incorporate the innovation" (Banbury and Mitchell, 1995: 161, 163). They found that the more often a firm was among the first to introduce TI, the greater its market share. In addition, the greater the number of competitors that introduced a similar TI, the greater the market share of firms that were first to introduce it. Finally, they found that while greater market share reduced 
the likelihood of business dissolution, TI provided little or no reduction in the likelihood of business dissolution net of the effects of the firm's market share.

Another point of view is offered by Christensen, Suárez, and Utterback (1998) who suggested that the performance impact of TI is dependent on the interaction between its technical and market characteristics. In the technical dimension, they differentiated between new technologies that result from an improvement in product component technology and those that are "architectural": innovative ways of linking proven components. In the market dimension, they distinguished between strategies addressing new market segments and those addressing established markets. They found that firms introducing TI that is architectural and targeted at new market segments (emerging segments in which a dominant design had not yet been established) had significantly higher probabilities of survival than firms introducing TI into established market segments, based on improvements in component technology. Also focusing on technical and market characteristics, Nerkar and Roberts (2004) found that while experience gained in markets "distal" to a focal innovation led to higher initial product sales, "proximal" technological experience explained new product success.

A final set of variables are provided by Gatignon et al. (2002) who develop and test constructs for differentiating "innovation" "locus," "type" and "characteristics." With respect to locus, they distinguish between innovations that affect "core subsystems" and those that affect "peripheral subsystems." Innovation types include "architectural" and "generational" innovation, while innovation characteristics differentiate between radical/incremental and competenceenhancing/competence-destroying innovations. To test the nomological validity of their constructs, they apply models of their impact on performance. Their results suggest that the greater the complexity of TI, the greater its perceived success, yet the longer it takes to introduce. TI affecting core subsystems, which was associated with "both new competence acquisition and with building on existing competencies" (ibid: 1118) is associated with the greatest commercial success. In line with Henderson and Clark (1990), they also find that "architectural" innovations are associated with increased time to introduction, but surprisingly, innovations in peripheral subsystems are associated with increased time to market as well.

In summary, these and a handful of other studies indicate the existence of several variables mediating the relationship between TI and performance. On the one hand, studies focusing on technical and market characteristics of TI illustrate how these affect the amount of value created by TI, and hence its impact on performance. They show that different dimensions in the knowledge and capabilities underlying these characteristics affect performance (Christensen et al., 1998; Gatignon et al., 2002; Nerkar and Roberts, 2004; Sheremata, 2004). On the other hand, studies emphasizing timing, appropriability, and complementary assets illustrate how these affect the value appropriated by an innovating firm (e.g. Banbury and Mitchell, 1995; Teece, 1987). Their focus on "valuable" innovations shows that market success is not sufficient to guarantee that TI will improve firm performance.

Nevertheless, there remains a pressing need for further delineation of the determinants of the performance outcomes of TI. Studies which broach this issue are still very few, and do not yet add up to a "solid" knowledge base. There is a need for further empirical testing and replication of the results of these pioneer studies in other contexts. For example, Gatignon et al. (2002) focus on modifications of existing products, which are only one subset of possible TI modes. Similarly, very few studies (Christensen et al. (1998) and Nerkar and Roberts (2004) are two notable exceptions) simultaneously consider technical and market determinants of the impact of TI on performance. There is therefore a very clear need for further work on highlighting 
determinants of the performance outcome of TI. In closing, Figure 5 summarizes the existing knowledge on the outcomes of technological innovation.

\section{In Search of a Theory on the Performance Impact of Technological Innovation}

"We stress that being new is not the same as being desirable. ... Recall Kimberly's (1981) comment that the study of innovation suffers from a pervasive positive bias" (McGrath et al., 1996: 392).

Managerial and academic effort in the recent past has focused intensely on issues related to innovation, with the implicit assumption that increased innovation would lead to improved firm performance. Nevertheless, the empirical facts are beginning to indicate that although innovativeness has increased, economic performance has not improved correspondingly (Kandybin and Kihn, 2004; Linder et al., 2003). The success rate of major innovations remains below 20\% (Rothaermel, 2001), and tests of the relationship between innovativeness and firm performance consistently exhibit mixed results (Capon et al., 1990; Li and Atuahene-Gima, 2001).

These findings indicate missing explanatory variables in the technological innovationperformance relationship. Since individual innovations can have more or less successful outcomes, it is not surprising to find an ambiguous overall impact of innovativeness on performance. What we require is a delineation of the factors - the innovation-level contingencies - which mediate or moderate the relationship between technological innovation and firm performance. We need a "circumstance-based" theory (Carlile and Christensen, 2005) that can explain how, when, and why technological innovation leads to improved firm performance. In other words, what are the determinants of the performance outcome of technological innovation? 


\section{Figure 5}

Drivers and Moderators of the Outcomes of Technological Innovation

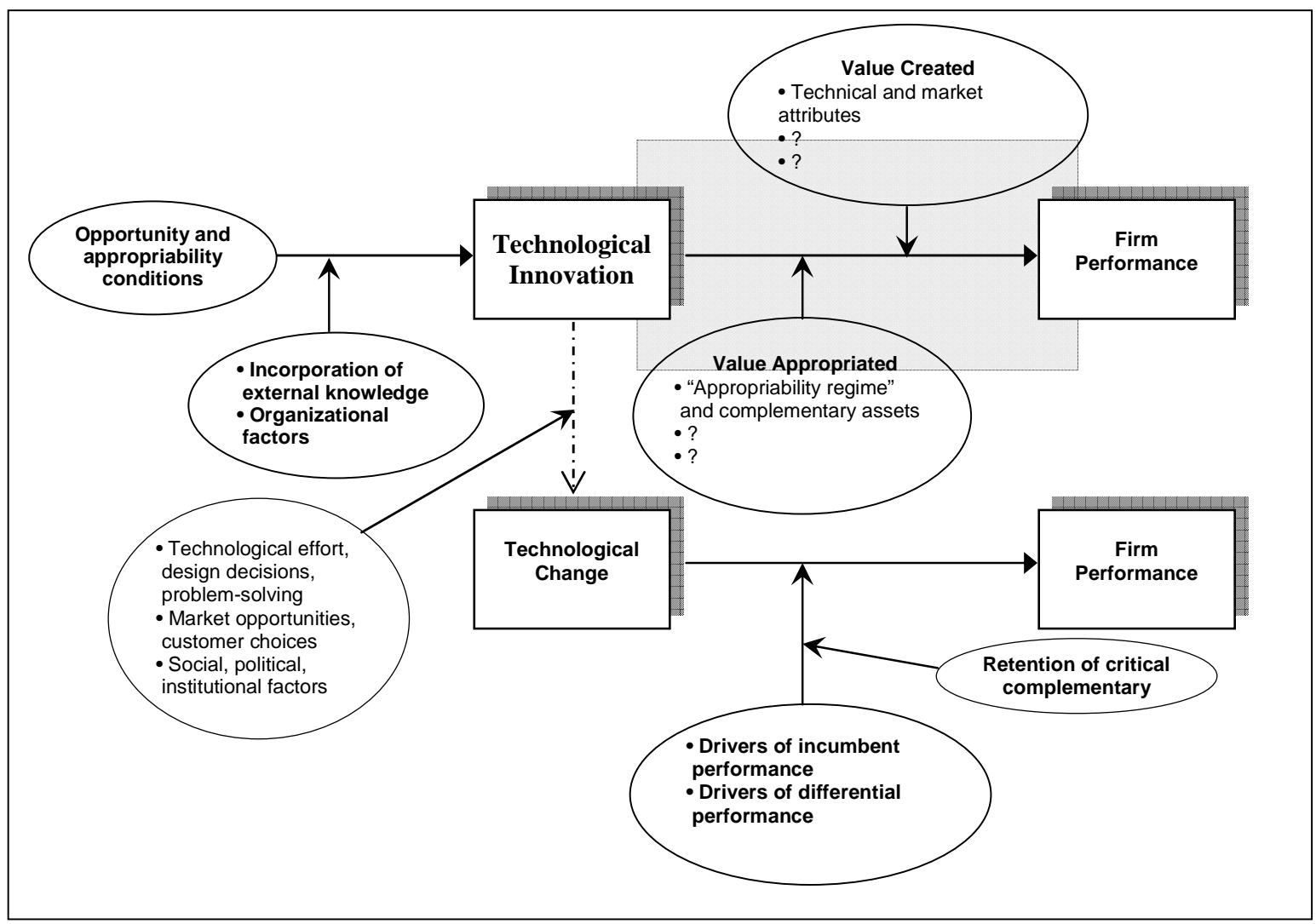

Our review encompassing 31 journals, 16 edited scholarly volumes, and over 30 books, with temporal boundaries from 1934 to the present, shows that the existing literature gives coherent explanations of the determinants of innovation outcomes and technical outcomes of technological innovation, as well as the determinants of performance outcomes of technological change. However, we have seen that relatively little light has been shed on the determinants of the performance outcomes of technological innovation. This area thus represents the next frontier for "innovation-performance" studies, as highlighted by the shaded portion of Figure 5. We need more studies that map out the contents of the "black box" mediating technological innovation and firm performance. While it is true that institutional and legitimacy factors often drive innovation (Abrahamson, 1991; Ferlie, Fitzgerald, Wood, and Hawkins, 2005; Young, Charns, and Shortell, 2001), it is also true that one of the most important reasons why firms innovate is in order to improve their performance (Burgelman and Rosenbloom, 1997; Zahra, 1996; Zahra and Covin, 1993).

Current work indicates that studies seeking to shed further light on the determinants of the performance outcome of technological innovation could fruitfully focus on two sub-constructs of performance: the amount of value created by TI and the amount of value appropriated by innovating firms. Firstly, the amount of value created by TI relative to competing firm offerings derives from the interaction between its technical and market characteristics and the focal firm's technological and customer knowledge and capabilities (Christensen et al., 1998; Clark, 1987; Danneels, 2002; Nerkar and Roberts, 2004). In addition, since value is created for 
consumers, aspects of the demand environment, such as the way in which they evaluate TI, and the way in which this evaluation changes as TI performance improves (Adner, 2002), are critical for explaining the impact of TI on firm performance. Thus studies able to: (1) characterize differential firm attributes (e.g. different aspects of technical and market knowledge and capabilities); (2) characterize different technical and market attributes of TI; and (3) characterize aspects of the demand environment, relating all or some of these to firm performance; will advance the search for determinants of the performance outcome of TI.

Secondly, since Teece's (1987) path-breaking paper, most work on value appropriation from TI has focused on factors affecting the imitability of innovations. Innovators are advised to center attention on avoiding imitation, failing which they should achieve a superior position in asset complementary to the innovation at a cost inferior to the anticipated amount of value up for grabs (Grant, 2002; Teece, 1987; Winter, 2000). Yet it is not clear that inimitability guarantees superior appropriation. For instance, in the case of innovation based on externally sourced technology, there remains the possibility of upstream holdup (Ghemawat, 1991) by technology suppliers. On the downstream end, Brandenburger and Stuart (2003) point out that the assumption that a monopoly can extract all the value created from consumers is not unassailable.

There is thus a need for further development in the theoretical understanding of the circumstances under which innovating firms can appropriate superior amounts of the value created by TI under competition. Recent developments in cooperative game theory (Brandenburger and Stuart, 2004; MacDonald and Ryall, 2004) integrated into the "microfoundations" of the resource-based view of the firm (Lippman and Rumelt, 2003) provide an opportunity for deepening this area of knowledge. This line of work offers an opportunity to highlight the determinants of the distribution of value created by TI among innovating firms, buyers, and suppliers. For instance, studies able to relate idiosyncratic firm endowments to superior "added-value" (Brandenburger and Stuart, 1996) or superior complementarity to a given technology, and hence to the amount of value appropriated, would further advance the search for the determinants of the performance outcome of TI.

\section{Conclusion}

"Just because innovation is important, that does not necessarily mean that pursuing innovation will be profitable for the firm" (Grant, 2002: 334). In this paper, we have argued that both empirical evidence and theoretical reflection challenge the positive bias inherent in most approaches to technological innovation. Anomalous results call for deeper theoretical development, and more refined empirical exploration of the determinants of the performance outcome of technological innovation. As a first step in this direction, we presented the results of an exhaustive review of the existing knowledge of the determinants of the outcomes of technological innovation. We characterized three distinct classes of outcomes and presented a model relating the different determinants uncovered in the literature to the various outcomes. We thus showed that while a lot of work has apparently focused on innovation "performance," studies actually explaining the performance impact of technological innovation are few and not well developed. Finally, in the light of the knowledge uncovered and recent developments in work on firm capabilities, we indicated possible avenues for further development of this critical area of research. 


\section{References}

Abernathy, W.J. and Clark, K.B. 1985, "Innovation: Mapping the Winds of Creative Destruction," Research Policy, 14(1): 3-22.

Abernathy, W.J. and Utterback, J.M. 1978, "Patterns of Industrial Innovation," Technology Review, 80(7): 40-47.

Abrahamson, E. 1991, "Managerial Fads and Fashions: The Diffusion and Rejection of Innovations," Academy of Management Review, 16: 586-612.

Acs, Z.J. and Audretsch, D.B. 1988, "Innovation in Large and Small Firms: An Empirical Analysis," American Economic Review, 78(4): 678-690.

Adner, R. 2002, "When are Technologies Disruptive? A Demand-Based View of the Emergence of Competition," Strategic Management Journal, 23(8): 667-688.

Afuah, A.N. 2000, "How Much do your Co-opetitors' Capabilities Matter in the Face of Technological Change?" Strategic Management Journal, 21(3): 387-404.

Ahuja, G. 2000, "Collaboration Networks, Structural Holes and Innovation: A Longitudinal Study," Administrative Science Quarterly, 45: 425-455.

Ahuja, G. and Katila, R. 2001, "Technological Acquisitions and the Innovation Performance of Acquiring Firms: A Longitudinal Study,” Strategic Management Journal, 22(3): 197-219.

Ahuja, G. and Lampert, C.M. 2001, "Entrepreneurship in the Large Corporation: A Longitudinal Study of How Established Firms Create Breakthrough Discoveries," Strategic Management Journal, 22: 521-543.

Amabile, T.M. 1988, "A Model of Creativity and Innovation in Organizations," In B.M. Staw, and L.L. Cummings (Eds.), Research in Organizational Behavior, Vol. 10: 123-167. Greenwich, CT.: JAI Press.

Amabile, T.M. 1997, "Motivating Creativity in Organizations: On Doing What You Love and Loving What You Do," California Management Review, 40(1): 39-58.

Anderson, P. and Tushman, M.L. 1990, "Technological Discontinuities and Dominant Designs: A cyclical model of technological change,” Administrative Science Quarterly, 35(4): 604633.

Andrew, J.P. 2005, Innovation 2005, Senior Management Survey, Boston Consulting Group Inc.

Andrew, J.P. and Sirkin, H.L. 2003, "Innovating for Cash," Harvard Business Review, 81(9): 7683.

Anton, J. and Yao, D. 1995, "Start-ups, Spin-offs and Internal Projects," Journal of Law, Economics and Organization, 11(362-378).

Arend, R.J. 1999, "Emergence of Entrepreneurs Following Exogenous Technological Change," Strategic Management Journal, 20(1): 31-47.

Arora, A. and Gambardella, A. 1994, "Evaluating Technological Information and Utilizing It: Scientific Knowledge, Technological Capability and External Linkages in Biotechnology," Journal of Economic Behavior and Organization, 24(1): 91-114.

Arrow, K. 1962, "Economic Welfare and the Allocation of Resources for Inventions," In R.R. Nelson (Ed.), The Rate and Direction of Inventive Activity: Economic and Social Factors, Princeton, NJ.: Princeton University Press. 
Arthur, W.B. 2001, “Competing Technologies: An Overview," In R.A. Burgelman, M.A. Maidique, and S.C. Wheelwright (Eds.), Strategic Management of Technology and Innovation: 298-308. New York: McGraw-Hill/Irwin.

Audretsch, D.B. 1991, "New firm survival and the technological regime," Review of Economics and Statistics, 68: 520-526.

Banbury, C.M. and Mitchell, W. 1995, "The Effect of Introducing Important Incremental Innovations on Market Share and Business Survival," Strategic Management Journal, 16 (Special Issue): 161-182.

Benner, M.J. and Tushman, M.L. 2002, "Process Management and Technological Innovation: A Longitudinal Study of the Photography and Paint Industries," Administrative Science Quarterly, 47: 676-706.

Benner, M.J. and Tushman, M.L. 2003, "Exploitation, Exploration and Process Management: The Productivity Dilemma Revisited," Academy of Management Review, 28(2): 238-256.

Bower, J.L. 1970. Managing the Resource Allocation Process. Homewood, IL.: Irwin.

Brandenburger, A. and Stuart, H.W., Jr. 2003. Biform Games. Working Paper, New York University and Colombia University. Available at: www.stern.nyu.edu/ abranden:15/1/04

Brandenburger, A.M. and Stuart, H.W., Jr. 1996, "Value-Based Business Strategy," Journal of Economics and Management Strategy, 5(1): 5-24.

Brown, S.L. and Eisenhardt, K.M. 1995, "Product Development: Past Research, Present Findings and Future Directions," Academy of Management Review, 20: 343-378.

Burgelman, R.A., Maidique, M.A. and Wheelwright, S.C. 2001, Strategic Management of Technology and Innovation, Boston: McGraw Hill/Irwin.

Burgelman, R.A., and Rosenbloom, R.S. 1997, "Technology Strategy: An Evolutionary Process Perspective," In M. L. Tushman, and P. Anderson (Eds.), Managing Strategic Innovation and Change: 273-286. New York: Oxford University Press.

Capon, N., Farley, J. U. and Hoenig, S. 1990, "Determinants of Financial Performance: A MetaAnalysis," Management Science, 36: 1143-1159.

Carlile, P. and Christensen, C.M. 2005, The Cycles of Theory Building in Management Research, Working Paper.

Cassiman, B., Colombo, M., Garrone, P. and Veugelers, R. 2003, The Impact of M\&A on the R\&D Process. An Empirical Analysis of the Role of Technological and Market Relatedness, Working Paper No. 500, IESE Business School, University of Navarra, Barcelona.

Cassiman, B. and Ueda, M. 2002, Optimal Project Rejection and New Firm Startups, Working Paper.

Cassiman, B. and Veugelers, R. 2002, Complementarity in the Innovation Strategy: Internal $R \& D$, External Technology Acquisition and Cooperation in R\&D, Working Paper.

Chandler, G.N. and Hanks, S.H. 1994, "Market Attractiveness, Resource-based Capabilities, Venture Strategies and Venture Performance," Journal of Business Venturing, 9: 331349.

Christensen, C.M. 1997, The Innovator's Dilemma, Boston, MA: Harvard Business School Press.

Christensen, C.M. and Bower, J.L. 1996, "Customer power, Strategic investment and the failure of Leading Firms,” Strategic Management Journal, 17(3): 197-218. 
Christensen, C.M., Suarez, F.F. and Utterback, J.M. 1998, "Strategies for Survival in FastChanging Industries," Management Science, 44(12): S207-S220.

Christiansen, J.A. 2000, Building the Innovative Organization: Management Systems that Encourage Innovation, Houndmills: MacMillan Press.

Clark, K.B. 1985, "The Interaction of Design Hierarchies and Market Concepts in Technological Evolution," Research Policy, 14(5): 235-251.

Clark, K.B. 1987, "Investment in New Technology and Competitive Advantage," In D.J. Teece (Ed.), The Competitive Challenge: Strategies for Industrial Innovation and Renewal: 5981. Cambridge, MA: Ballinger Publishing Company.

Cohen, W.M. and Klepper, S. 1992, "The Anatomy of Industry R\&D Intensity Distributions," American Economic Review, 82: 773-799.

Cohen, W.M. and Levin, R.C. 1989, "Empirical studies of innovation and market structure," In R. Schmalensee, and R.D. Willig (Eds.), Handbook of Industrial Organization, Vol. 2: 1059-1107. Amsterdam: North Holland.

Cohen, W.M. and Levinthal, D.A. 1989, "Innovation and Learning: The Two Faces of R\&D," Economic Journal, 99: 569-596.

Cohen, W.M. and Levinthal, D.A. 1990, “Absorptive Capacity: A New Perspective on Learning and Innovation," Administrative Science Quarterly, 35(1): 128-152.

Cohen, W.M. and Levinthal, D.A. 1994, "Fortune favors the prepared firm," Management Science, 40(2): 227-251.

Cooper, A.C. and Schendel, D. 1976, "Strategic Responses to Technological Threats," Business Horizons, 19(1): 61-69.

Cyert, R.M. and March, J.G. 1963, A Behavioral Theory of the Firm, Englewood Cliffs, NJ.: Prentice-Hall.

Danneels, E. 2002, "The Dynamics of Product Innovation and Firm Competences," Strategic Management Journal, 23(12): 1095-1121.

David, P. 1985, “Clio and the Economics of QWERTY," American Economic Review, 75(2): 332337.

Dosi, G. 1982, “Technological Paradigms and Technological Trajectories," Research Policy, 11(3): 147-162.

Dosi, G. 1984, Technical Change and Industrial Transformation, New York: St Martin's.

Drucker, P.F. 1954, The Practice of Management, New York: HarperCollins.

Drucker, P.F. 1985, Innovation and Entrepreneurship, New York: Harper\&Row.

Duelli, J. and Hültenschmidt, N. 2002, Managing Innovation Strategy, Bain and Company.

Ferlie, E., Fitzgerald, L., Wood, M. and Hawkins, C. 2005, "The Nonspread of Innovations: The Mediating Role of Professionals,” Academy of Management Journal, 48(1): 117-134.

Foster, R. 1986, Innovation: The Attacker's Advantage, New York: Summit Books.

Gatignon, H., Tushman, M.L., Smith, W., and Anderson, P. 2002, “A Structural Approach to Assessing Innovation: Construct Development of Innovation Locus, Type and Characteristics," Management Science, 48(9): 1103-1122.

Ghemawat, P. 1991, Commitment: The Dynamic of Strategy, New York: Free Press. 
Gilbert, R.J. and Newbery, D.M.G. 1982, "Preemptive Patenting and the Persistence of Monopoly," American Economic Review, 72: 514-526.

Gilbert, R.J. and Newbery, D.M.G. 1984a, "Preemptive Patenting and the Persistence of Monopoly: Reply," American Economic Review, 74: 251-253.

Gilbert, R.J. and Newbery, D.M.G. 1984b, "Uncertain Innovation and the Persistence of Monopoly: Comment," American Economic Review, 74(1): 238-242.

Gort, M. and Klepper, S. 1982, “Time Paths in the Diffusion of Product Innovations," Economic Journal, 92(367): 630-653.

Grant, R.M. 2002, Contemporary Strategy Analysis: Concepts, Techniques, Applications, (4th ed.). Oxford: Blackwell.

Greve, H.R. 2003, “A Behavioral Theory of R\&D Expenditures and Innovations: Evidence from Shipbuilding," Academy of Management Journal, 46(6): 685-702.

Hamel, G. 2000, Leading the Revolution, Boston: Harvard Business School Press.

Haneda, S. and Odagiri, H. 1998, "Appropriation of Returns from Technological Assets and the Values of Patents and R\&D in Japanese High-Tech Firms," Economics of Innovation and New Technology, 7: 303-321.

Henderson, R.M. 1993, "Underinvestment and Incompetence as Responses to Radical Innovation: Evidence from the Photolithographic Equipment Industry," Rand Journal of Economics, 24(2): 248-270.

Henderson, R.M. and Clark, K.B. 1990, "Architectural Innovation: The Reconfiguration of Existing Product Technologies and the Failure of Established Firms," Administrative Science Quarterly, 35(1): 9-30.

Hill, C.W.L. and Rothaermel, F.T. 2003, "The Performance of Incumbent Firms in the Face of Radical Technological Innovation," Academy of Management Review, 28(2): 257-274.

Iansiti, M., McFarlan, F.W. and Westerman, G. 2003, "Leveraging the Incumbent's Advantage," MIT Sloan Management Review, 44(4): 58-64.

Jones, N. 2003, "Competing after Radical Technological Change: The Significance of Product Line Management Strategy,” Strategic Management Journal, 24(13): 1265-1287.

Kandybin, A. and Kihn, M. 2004, "Raising Your Return on Innovation Investment," Strategy+Business(35): 1-12.

Kanter, R.M. 1996, "When a Thousand Flowers Bloom: Structural, Collective and Social Conditions for Innovation in Organizations," In P.S. Myers (Ed.), Knowledge Management and Organization Design: 169-211, Boston: Butterworth-Heinemann.

Katz, M.L. and Shapiro, C. 1985, "Network Externalities, Competition and Compatibility," American Economic Review, 75(3): 424-440.

Katz, M.L. and Shapiro, C. 1986, "Technology Adoption in the Presence of Network Externalities," Journal of Political Economy, 94(4): 822-841.

Kim, W.C. and Mauborgne, R. 1999, "Strategy, Value Innovation and the Knowledge Economy,” Sloan Management Review, 40(3): 41-54.

Kimberly, J.R. 1981, "Managing Innovation," In P.C. Nystrom and W.H. Starbuck (Eds.), Handbook of Organizational Design, Oxford: Oxford University Press.

Klepper, S. and Sleeper, S. 2002, Entry by Spinoffs, Working Paper.

Knott, A.M. 2003, "Persistent Heterogeneity and Sustainable Innovation," Strategic Management Journal, 24(8): 687-705.

36 - IESE Business School-University of Navarra 
Lawless, M.W. and Anderson, P.C. 1996, "Generational Technological Change: Effects of Innovation and Local Rivalry on Performance," Academy of Management Journal, 39(5): 1185-1217.

Leiblein, M.J., Reuer, J.J. and Dalsace, F. 2002, "Do Make or Buy Decisions Matter? The Influence of Organizational Governance on Technological Performance," Strategic Management Journal, 23: 817-833.

Leifer, R., McDermott, C.M., O'Conner, G.C., Peters, L.S., Rice, M. and Veryzer, R.W. 2000, Radical Innovation: How Mature Companies Can Outsmart Upstarts, Boston: Harvard Business School Press.

Leiponen, A. 2000, "Competencies, Innovation and Profitability of Firms," Economics of Innovation and New Technology, 9: 1-24.

Lerner, J. 1997, "The Empirical Exploration of a Technology Race: The Winchester Disk Drive Industry, 1972-1988," Rand Journal of Economics, 28(2): 228-247.

Levin, R.C., Cohen, W.M. and Mowery, D.C. 1985, "R\&D Appropriability, Opportunity and Market Structure: New evidence of some Schumpeterian hypotheses," American Economic Review, 75(2): 20-24.

Levin, R.C., Klevorick, A.K., Nelson, R.R. and Winter, S.G. 1987, "Appropriating the Returns from Industrial Research and Development," Brookings Papers on Economic Activity, 3(783-820).

Li, H. and Atuahene-Gima, K. 2001, "Product Innovation Strategy and the Performance of New Technology Ventures in China," Academy of Management Journal, 44(6): 1123-1134.

Linder, J.C., Jarvenpaa, S. and Davenport, T.H. 2003, "Toward an Innovation Sourcing Strategy," MIT Sloan Management Review, 44(4): 43-49.

Lippman, S.A. and Rumelt, R.P. 2003, “A Bargaining Perspective on Resource Advantage,” Strategic Management Journal, 24: 1069-1086.

MacDonald, G. and Ryall, M.D. 2004, "How do Value Creation and Competition Determine Whether a Firm Appropriates Value?” Management Science, 50(10): 1319-1333.

Markides, C.C. 1997, “Strategic Innovation,” Sloan Management Review, 38(3): 9-23.

McEvily, S. K. and Chakravarthy, B. 2002, "The Persistence of Knowledge-Based Advantage: An Empirical Test for Product Performance and Technological Knowledge," Strategic Management Journal, 23: 285-305.

McGrath, R.G., Ming-Hone, T., Venkataraman, S. and MacMillan, I.C. 1996, "Innovation, Competitive Advantage and Rent: A Model and Test," Management Science, 42(3): 389403.

Methe, D., Swaminathan, A., Mitchell, W. and Toyama, R. 1997, "The Underemphasized Role of Diversifying Entrants and Industry Incumbents as the Sources of Major Innovations," In H. Thomas and D. O'Neal (Eds.), Strategic Discovery: Competing in New Areas: 99-116. New York: Wiley.

Mitchell, W. 1989, "Whether and When? Probability and Timing of Incumbents' Entry into Emerging Industrial Subfields," Administrative Science Quarterly, 34(2): 208-230.

Mitchell, W. 1991, "Dual Clocks: Entry Order Influences on Incumbent and Newcomer Market Share and Survival when Specialized Assets Retain their Value," Strategic Management Journal, 12(2): 85-100. 
Mitchell, W. and Singh, K. 1996, "Survival of Businesses using Collaborative Relationships to Commercialize Complex Goods," Strategic Management Journal, 17: 169-195.

Mowery, D.C. and Rosenberg, N. 1979, “The Influence of Market Demand upon Innovation: A Critical Review of some Recent Empirical Studies," Research Policy, 8(2): 102-153.

Nagarajan, A. and Mitchell, W. 1998, "Evolutionary Diffusion: Internal and External Methods Used to Acquire Encompassing, Complementary and Incremental Technological Changes in the Lithotripsy Industry," Strategic Management Journal, 19(11): 1063-1077.

Nelson, R.R. and Winter, S.G. 1974, "Neoclassical vs. Evolutionary Theories of Economic Growth: Critique and Prospectus," Economic Journal, 84: 886-905.

Nelson, R.R. and Winter, S.G. 1982, An Evolutionary Theory of Economic Change, Cambridge, MA: Belknap Press.

Nerkar, A. and Roberts, P.W. 2004, "Technological and Product-Market Experience and the Success of New Product Introductions in the Pharmaceutical Industry," Strategic Management Journal, 25: 779-799.

Nicholls-Nixon, C.L. and Woo, C.Y. 2003, "Technology Sourcing And Output Of Established Firms In A Regime of Encompassing Technological Change," Strategic Management Journal, 24(7): 651-666.

0’Brien, J.P. 2003, "The Capital Structure Implications of Pursuing a Strategy of Innovation," Strategic Management Journal, 24(5): 415-431.

Pavitt, K. and Soete, L. 1980, "Innovative Activities and Export Shares: Some Comparisons between Industries and Countries,” In K. Pavitt (Ed.), Technical Innovation and British Economic Performance, London: Macmillan.

Pfeffer, J. and Salancik, G.R. 1978, The External Control of Organizations: A Resource Dependence Perspective, New York: Harper and Row.

Porter, M.E. 1985, Competitive Advantage: Creating and Sustaining Superior Performance, New York: Free Press.

Reinganum, J.F. 1983, "Uncertain Innovation and the Persistence of Monopoly," American Economic Review, 73(4): 741-748.

Reinganum, J.F. 1984, "Uncertain Innovation and the Persistence of Monopoly: Reply," American Economic Review, 74(1): 243-246.

Rogers, E.M. 2003, Diffusion of Innovations, (5th ed.). New York: Free Press.

Rosenbloom, R.S. 2000, "Leadership, Capabilities and Technological Change: The Transformation of NCR in the Electronic Era," Strategic Management Journal, 21: 10831103.

Rothaermel, F.T. 2001, "Incumbent's Advantage through Exploiting Complementary Assets via Interfirm Cooperation,” Strategic Management Journal, 22(6/7): 687-699.

Rumelt, R.P. 1987, “Theory, Strategy and Entrepreneurship,” In D.J. Teece (Ed.), The Competitive Challenge: Strategies for Industrial Innovation and Renewal: 137-158. Cambridge, MA: Ballinger.

Sahal, D. 1981, Patterns of Technological Innovation, Reading, MA.: Addison-Wesley.

Sahal, D. 1985, “Technological guideposts and innovation avenues," Research Policy, 14(2): 61.

Salant, S.W. 1984, "Preemptive Patenting and the Persistence of Monopoly: Comment," American Economic Review, 74: 247-250. 
Scherer, F.M. 1967, "Market Structure and the Employment of Scientists and Engineers," American Economic Review, 57(June): 524-531.

Schilling, M.A. 2002, "Technology Success and Failure in Winner-Take-All Markets: The Impact of Learning Orientation, Timing and Network Externalities," Academy of Management Journal, 45(2): 387-398.

Schumpeter, J.A. 1934, The Theory of Economic Development, London: Oxford University Press.

Schumpeter, J.A. 1942, Capitalism, Socialism and Democracy, (3rd ed.). New York: Harper and Row.

Scott, J.T. 1984, "Firm versus Industry Variability in R\&D Intensity," In Z. Griliches (Ed.), R\&D, Patents and Productivity: 233-248. Chicago: University of Chicago Press.

Shamsie, J., Phelps, C. and Kuperman, J. 2004, "Better Late Than Never: A Study of Late Entrants in Household Electrical Equipment," Strategic Management Journal, 25(1): 6984.

Sheremata, W.A. 2004, "Competing Through Innovation in Network Markets: Strategies for Challengers," Academy of Management Review, 29(3): 359-377.

Suarez, F.F. and Utterback, J.M. 1995, “Dominant Designs and the Survival of Firms," Strategic Management Journal, 16(6): 415-430.

Sull, D.N., Tedlow, R.S. and Rosenbloom, R.S. 1997, "Managerial Commitments and Technological Change in the U.S. Tire Industry," Industrial and Corporate Change, 6(2): 461-501.

Teece, D.J. 1987, "Profiting from Technological Innovation: Implications for Integration, Collaboration, Licensing and Public Policy," In D.J. Teece (Ed.), The Competitive Challenge: Strategies for Industrial Innovation and Renewal: 185-219. Cambridge, MA: Ballinger Publishing Company.

Teece, D.J. 2003, "The Strategic Management of Technology and Intellectual Property," In D.0. Faulkner and A. Campbell (Eds.), The Oxford Handbook of Strategy, Vol. I: A Strategy Overview and Competitive Strategy: 132-166. Oxford: Oxford University Press.

Tegarden, L.F., Hatfield, D.. and Echols, A.E. 1999, "Doomed from the Start: What is the Value of Selecting a Future Dominant Design?” Strategic Management Journal, 20(6): 495518.

Tripsas, M. 1997, "Unraveling the Process of Creative Destruction: Complementary Assets and Incumbent Survival in the Typesetter Industry," Strategic Management Journal, 18(Summer Special Issue): 119-142.

Tushman, M.L. and Anderson, P. 1986, "Technological Discontinuities and Organizational Environments," Administrative Science Quarterly, 31(3): 439-465.

Tushman, M.L. and Anderson, P. (Eds.). 1997, Managing Strategic Innovation and Change, New York: Oxford University Press.

Utterback, J.M. and Abernathy, W.J. 1975, "A Dynamic Model of Process and Product Innovation," Omega, 33: 639-656.

Utterback, J.M. and Suarez, F.F. 1993, "Patterns of Industrial Evolution, Dominant Designs and Firms' Survival," In R.A. Burgelman and R.S. Rosenbloom (Eds.), Research on Technological Innovation, Management and Policy, Vol. 5: 47-87. Greenwich, Conn.: JAI Press. 
Winter, S.G. 1984, "Schumpeterian Competition in Alternative Technological Regimes," Journal of Economic Behavior and Organization, 5 (September-December): 287-320.

Winter, S.G. 2000, “Appropriating the Gains from Innovation,” In G.S. Day, P.J.H. Schoemaker and R. E. Gunther (Eds.), Wharton on Managing Emerging Technologies: 242-265. New York: Wiley.

Young, G.J., Charns, M.P. and Shortell, S.M. 2001, “Top Manager and Network Effects on the Adoption of Innovative Management Practices: A Study of TQM in a Public Hospital System," Strategic Management Journal, 22: 935-951.

Zahra, S.A. 1996, "Technology Strategy and Financial Performance: Examining the Moderating Role of the Firm's Competitive Environment," Journal of Business Venturing, 11: 189219.

Zahra, S.A. and Covin, J.G. 1993, "Business Strategy, Technology Policy and Company Performance," Strategic Management Journal, 14: 451-478.

Zahra, S.A. and George, G. 2002, "Absorptive Capacity: A Review, Reconceptualization and Extension," Academy of Management Review, 27(2): 185-203.

Zahra, S.A. and Neilsen, A.P. 2002, "Sources of Capabilities, Integration and Technology Commercialization,” Strategic Management Journal, 23(5): 377-398. 